\title{
Surface-ocean dynamics during eccentricity minima: a comparison between interglacial Marine Isotope Stage (MIS) 1 and MIS 11 on the Iberian Margin
}

\author{
Palumbo Eliana ${ }^{1,{ }^{*}}$, Voelker Antje H.L. ${ }^{2,3}$, Flores Jose Abel ${ }^{4}$, Amore Ornella F. ${ }^{5}$
}

1 Independent Researcher, Via Roma SNC - Pco Adelaide, 81010 Dragoni, CE, Italy

2 Divisão de Geologia e Georecursos Marinhos, Instituto Português do Mar e da Atmosfera (IPMA), Rua

Alfredo Magalhães Ramalho 6, 1495-006 Lisboa, Portugal

${ }^{3}$ Centre of Marine Sciences (CCMAR), Universidade do Algarve, Campus de Gambelas, 8005-139

Faro, Portugal

4 Departamento de Geología, Universidad de Salamanca, 37008 Salamanca, Spain

5 Dipartimento di Scienze e tecnologia, Università degli Studi del Sannio, 82100 Benevento, Italy

* Corresponding author : Eliana Palumbo, email address : eliana.palumbol@istruzione.it

\begin{abstract}
:
Understanding interglacial climate variability is a key issue in the scientific community. Here we compared records from Marine Isotope Stage (MIS) 11 to those from MIS 1 (Holocene) as they are perceived to be possible analogs. Our study on the lberian Margin, a key area to investigate surface dynamics in the Atlantic Ocean, incorporates coccolithophore assemblage and alkenone data of core MD03-2699 and their statistical analyses. Evaluating similarities between MIS 11 and MIS 1 depends on the way the two MIS are being aligned, i.e. at the deglaciation or based on the precession signal. During the deglaciation of either MIS 12 or MIS 2, the Iberian Margin was affected by abrupt decreases in SST and in coccolithophores' paleoproductivity caused by the arrival of subpolar surface waters. Just prior to the decline, in both the intervals, the Portugal Current affected the studied site, although a possible difference in upwelling strength is here suggested and related to more intense westerlies during the last glacial than the late MIS 12. Similar surface-ocean dynamics occurred at the onset of both MIS 11 and MIS 1 as indicated by the prevalence of the Iberian Poleward Current and sometimes the Azores Current, although the subtropical waters were more oligotrophic during the MIS 2 deglaciation than the MIS 12 one. Synchronizing our records according to the precession cycles aligns the early-to-mid Holocene with the second, warmer phase of MIS 11c. During both these intervals, the western Iberian Margin was mainly affected by the Iberian Poleward Current that transported more temperate-warm, mesotrophic surface waters during MIS 11c than during the early-to-mid Holocene. During the early to mid-Holocene the Iberian Margin endured incursions of colder surface waters that did not occur during MIS 11c allowing us to hypothesize that the studied site experienced, from a paleoceanographic point of view, a more stable period during MIS 11c than the early Holocene. Finally, spectral analysis suggests the role of full, half and fourth precession components in driving surface-ocean variability during MIS 11 and during the last 24 kyr BP.
\end{abstract}




\section{Highlights}

- Comparison of two eccentricity minima interglacials with different duration Evaluation of surfaceocean dynamics during MIS 11 vs. MIS 1 off W Iberia Both experienced different productivity regimes despite similar surface temperatures. Important role of full, half and fourth precession cycles in surfaceocean dynamics.

Keywords : Eccentricity minimum, Coccolithophores, Surface-ocean evolution, Statistical analysis, Precession cycles, Iberian Margin 


\section{Introduction}

During the last decade, many studies focused on the possible analogy between Marine

54 Isotope Stage (MIS) 11 and the Holocene (Hodell et al., 2000; Loutre, 2003; Loutre and Berger,

55 2003; Rohling et al., 2010; Tzedakis, 2010; Kandiano et al., 2012; Bubenshchikova et al., 2015).

56 Both interglacial periods are characterized by minima in Earth's eccentricity; a particular

57 configuration that occurred only once more during the last 1 Myr, i.e. during MIS 19. On the other

58 hand, precession and obliquity variability during the target period $5 \mathrm{ka}$ Before Present (BP) to $60 \mathrm{ka}$

59 After Present was not identical to the one of MIS 11 (Loutre and Berger, 2000; 2003). Despite the

60 imperfect match in the orbital parameters' configuration, MIS 11 and MIS 1 show a high analogy in

61 terms of the insolation signal with similar values of atmospheric (pre-human activity) $\mathrm{CO}_{2}$

62 concentrations (Loutre and Berger, 2000; 2003 and references therein). Although attention shifted

63 to other possible analogs during the last years, such as MIS 19 (Pol et al., 2010; Tzedakis et al.,

64 2012; Emanuele et al., 2015; Ferretti et al., 2015), the scientific discussion on MIS 11 is still

65 ongoing (e.g., Candy et al., 2014; Bubenshchikova et al., 2015; Maiorano et al., 2015; Oliveira et

66 al., 2016; Saavedra-Pellitero et al., 2017; Marino et al., 2018). While not often mentioned in this

67 context, other interglacials (i.e., MIS 5e, 9e, 15a, 15e) also show this phasing, but with varying

68 amounts of precessional power and obliquity amplitude (Yin and Berger, 2010). 
In order to understand possible analogies also in terms of common evolution, different alignment techniques were previously proposed. The first option is based on insolation and orbital parameters, whereby the June insolation signals through precessional variations are aligned following Loutre and Berger (2000, 2003). The second option, used by the EPICA Community Members (2004) for the EPICA Dome C (EDC) Antarctic ice core, lines up Terminations I and V using obliquity sinusoidal curves. Tzedakis (2010) compared southern European tree populations during MIS 11 and MIS 1 using the criteria of obliquity and precession alignments. Rohling et al. (2010) used the alignment method of sea-level signal synchronization. In any case, when MIS 11c is compared to the Holocene we have to take into account that MIS 11c appears to be an exceptionally long interglacial, generally with a 2-3 times longer duration than the Holocene (Past Interglacials Working Group of PAGES, 2016). The MIS 11c duration is also longer than many of the other interglacials, none of which (except for MIS 13, see below) have mean durations twice as long as the Holocene (Past Interglacials Working Group of PAGES, 2016).

Because of the keen interest in MIS 11 climate evolution, studies exist from different areas and from continental and marine archives (e.g., Ayling et al., 2015; Benardout, 2015; Candy et al., 2014; Cheng et al., 2016; D’Anjou et al., 2013; Fawcett et al., 2011; Milker et al., 2013; Antoine et al., 2016; Regattieri et al., 2016; Reyes et al., 2014; Stepanchuk and Moigne, 2016; SaavedraPellitero et al., 2017). Accordingly, an increasing number of deep-sea cores provided insights into surface-ocean dynamics (e.g., Dickson et al., 2010; Voelker et al., 2010; Kandiano et al., 2012; Vázquez Riveiros et al., 2013; Maiorano et al., 2015; Saavedra-Pellitero et al., 2017), including on the Iberian Margin (Rodrigues et al., 2011, 2017; Amore et al., 2012; Palumbo et al., 2013a; Oliveira et al., 2016; Sanchéz-Goñi et al., 2016). Due to the high sedimentation rate, which allows detecting millennial-to-centennial scale variability, the Iberian Margin is considered a key area for paleoclimate studies (e.g., Shackleton et al., 2000; Hodell et al., 2013). In addition, this area is oceanographically characterized by the Portugal-Current System and seasonal upwelling (Ríos et al., 1992; Fiúza et al., 1998; Pérez et al., 2001; Coelho et al., 2002; Peliz et al., 2005; Relvas et al., 2007).

The Iberian Margin has been intensely studied over the last two decades in order to better understand late Quaternary glacial-interglacial and millennial-scale climate variability (e.g., Skinner et al., 2003; Eynaud et al., 2009; Amore et al., 2012; Hodell et al., 2013; Margari et al., 2014; Marino et al., 2014; Oliveira et al., 2016; Salgueiro et al., 2010; Shackleton et al., 2000; Voelker et al., 2010). Several studies provided detailed Sea-Surface Temperature (SST) and paleoproductivity reconstructions for MIS 11 and MIS 1 and discussed their relationships to surface-ocean dynamics 
(Rodrigues et al., 2010; Rodrigues et al., 2011, 2017; Amore et al., 2012; Palumbo et al., 2013a, b; Marino et al., 2014; Maiorano et al., 2015).

Our choice to use coccolithophores as paleoclimate proxy is related to their ability in recording the smallest climatic fluctuations thanks to their sensitive response to SST, nutrient availability, salinity, and sunlight changes (e.g., McIntyre and Bé, 1967; Baumann and Freitag, 2004; Moita et al., 2010; Poulton et al., 2017; Guerreiro et al., 2017; Ausin et al., 2018). Previous studies demonstrated their role to reconstruct changes in the main surface-ocean currents off Portugal, in particular in combination with alkenones data (Amore et al., 2012; Palumbo et al., 2013a, b). The main aim of our study is defining possible analogies between the dynamics that led from the glacials to the interglacials and the evolution of the full interglacial conditions focusing on the characteristics of the main surface ocean currents affecting our study site. Previous studies of the coccolithophore assemblages revealed different structures depending on the prevailing surfaceocean currents and thus nutrient availability and SST during the middle and late Pleistocene to Holocene (Amore et al., 2012; Palumbo et al., 2013a, b). Whereas the species Emiliania huxleyi dominates the late glacial to Holocene assemblage (Palumbo et al., 2013a), MIS 11 falls into the acme of Gephyrocapsa caribbeanica (Amore et al., 2012; Palumbo et al., 2013b), both species belonging to the Noelaerhabdaceae family. E. huxleyi, a cosmopolitan species, can tolerate large temperatures ranges and both eutrophic and oligotrophic conditions (Okada and McIntyre, 1979; Winter et al., 1994). The paleoecology of G. caribbeanica is still under discussion. Its dominance, a global and synchronous event (e.g., Flores et al., 1999, 2003; Baumann and Freitag, 2004), could potentially be caused by a rapid phylogenetic evolution.

In this study, we evaluate possible similarities or differences in surface-ocean changes and their impact on coccolithophores during MIS 11 against MIS 1 using previously published coccolithophore assemblage data (Amore et al., 2012; Palumbo et al., 2013a, b) from sediment core MD03-2699 (Fig. 1). We re-analyze the data with statistical analyses, in particular principal component analysis (PCA), to better quantify the relationships between coccolithophore species and environmental conditions. Assessing conditions during these particular periods helps evaluating if one of the MIS 11/MIS 1 alignments fits better with the coccolithophores' evidence or if a compromise between both solutions is needed.

\section{Regional Setting}

Sediment core MD03-2699 $\left(39^{\circ} 02.20^{\prime} \mathrm{N}, 10^{\circ} 39.63^{\prime} \mathrm{W}\right)$ was recovered on the Estremadura promontory off central Portugal (Fig. 1). In this region, the hydrography is connected to the Portugal Current System and strongly influenced by the seasonal and intra-seasonal migrations of 
the Azores High pressure center. The Portugal Current System was described in detail in previous studies (Ríos et al., 1992; Fiúza et al., 1998; Pérez et al., 2001; Coelho et al., 2002; Peliz et al., 2005; Relvas et al., 2007). All the system's main currents share a common link to the Gulf Stream waters with the subtropical gyre's southwestward recirculation, i.e. the Portugal Current, branching off from the North Atlantic Current (Fig. 1). The Azores Current, a unique current crossing the North Atlantic's subtropical gyre near $34^{\circ} \mathrm{N}$, branches off directly from the Gulf Stream (Klein and Siedler, 1989) and can thus transport low latitude signals directly to the Iberian margin. The mixed surface waters between the North Atlantic Current and the Azores Current are sometimes referred to as the North Atlantic Transitional Waters (Schwab et al., 2012).

During spring/summer, the pressure cell of the Azores High moves northward leading to an intensification of the westerly winds. This activates upwelling on the western Iberian margin and leads to the prevalence of the cool, less saline and nutrient-rich Portugal Current in the study area (Fig. 1a). The southward migration of the Azores High during autumn/winter causes a reduction of westerly winds' intensity, which favors the northward flow of the warm, salty and nutrient-poor Iberian Poleward Current over the area (Fig. 1b). The Portugal Current transports Eastern North Atlantic Central Waters (ENACW) of subpolar origin (ENACWsp; Fig. 1a) southward, which usually flows below its subtropical counterpart, ENACWst, transported northward by the Iberian Poleward Current (Fig. 1b). The Iberian Poleward Current is seen as a northern branch of the Azores Current (Peliz et al., 2005; Fig. 1).

The Azores High also experiences intra-seasonal variability, in particular during winter, which is reflected in the North Atlantic Oscillation (NAO; Hurrell, 1995), the most relevant atmospheric phenomenon in the North Atlantic sector. Negative values of the NAO index indicate a reduced pressure gradient between the Azores High and Icelandic Low (Hurrell, 1995; Fig. 1). This atmospheric setting leads to a reduction of the westerlies over the eastern North Atlantic (Trigo et al., 2004), to generally warm conditions over Iberia (Hurrell and Deser, 2010) and to an intensification of the Iberian Poleward Current (Sánchez et al., 2007). Positive modes of the NAO correspond to an increased pressure gradient causing generally cold conditions and a strengthening of the westerlies and of the upwelling off Iberia (Hurrell, 1995; Sánchez et al., 2007; Hurrell and Deser, 2010).

\section{Material and Methods}

\subsection{Coccolithophore assemblages and alkenones}

For the initial assemblage analyses (Amore et al., 2012; Palumbo et al., 2013a, b), 219 samples were analyzed for the MIS 12 to MIS 11 interval (445-360 kyr) and 150 samples for the 
MIS 2 to MIS 1 interval. In both intervals, sample spacing was $2 \mathrm{~cm}$ leading to a temporal resolution of about $0.4 \mathrm{kyr}$ in the MIS 12 to MIS 11 interval and of about $0.140 \mathrm{kyr}$ during the last $24 \mathrm{kyr}$ BP. With the exception of the Umbilicosphaera sibogae record for the MIS 12-MIS 11 period, which is here published for the first time, we re-analyzed these published data. The MD032699 samples for coccolithophore assemblages were prepared following Flores and Sierro (1997). Details on the assemblage analyses are provided in Palumbo et al. (2013a, b). Total abundance or abundance of a particular taxon is expressed as number of coccoliths per gram of sediment (\#coccoliths/g of sediment) or as relative abundance (\%). Fluxes are presented as Nannofossil Accumulation Rate (NAR, \#coccoliths/g of sediment $* \mathrm{~cm}^{-2 *} \mathrm{kyr}^{-1}$ ). Due to their ecological sensitivity to specific marine environmental factors, selected coccolithophore taxa or group of taxa have been identified as good indicators for the main surface-ocean currents characterizing the Portugal Current System (Table 1) (Amore et al., 2012; Palumbo et al., 2013a, b). The alkenone based data (SST, $\mathrm{C}_{37: 4} \%$ ) were originally published in Rodrigues et al. $(2010,2011)$ and Palumbo et al. (2013a) and their paleoceanographic implications are listed in table 1 .

\subsection{Alignments of the Marine Isotope Stages}

For extricating potential analogies in the surface currents' evolution between MIS 11 and MIS 1 (Holocene) off the Iberian Margin, correctly aligning the records of both periods is essential. Different options exist to align the two MIS and each version has implications for comparing the two MIS and for predicting a possible length of the current interglacial.

Figure 2 shows the two different approaches tested in this paper based on the SST data: we use 1) the termination/deglaciation alignment and 2) the precession alignment. When the deglaciations are considered as tie point, the pronounced SST drops during Terminations V and I are lined up, i.e. Heinrich-type event 4 (between 428 and 427 ka; Rodrigues et al., 2011) with the 18-15 ka BP interval (Rodrigues et al., 2010). Following the precession synchronization criterion, the SST records were aligned comparing the second half of MIS 11c, i.e. the one coinciding with the sea-level highstand, with the early-to-mid Holocene.

\subsection{Age models}

In this study, we use the age models previously published for core MD03-2699. The age model for the MIS 1 to MIS 2 interval (Rodrigues et al., 2010) is based on calibrated ${ }^{14} \mathrm{C}$ ages during the Holocene and a correlation between the SST records of cores MD03-2699 and MD012444 (Martrat et al., 2007) during the glacial period. The mid-Brunhes chronology (Voelker et al., 2010) was established by relating the benthic $\delta^{18} \mathrm{O}$ record of core MD03-2699 to the one of ODP 
Site 980 (McManus et al., 1999) on its LR04 chronology (Lisiecki and Raymo, 2005). The average sedimentation rate is $14 \mathrm{~cm} / \mathrm{kyr}$ for the MIS 1 interval and $\sim 6 \mathrm{~cm} / \mathrm{kyr}$ for MIS 11 .

\subsection{Statistical analyses}

Principal Components Analysis (PCA), a tool included in the software PAleontological Statistics (PAST; Hammer et al., 2001), was applied to three time intervals: 1) the complete time series of the respective interval; 2) the full interglacial period; and 3) the deglacial interval. PCA finds hypothetical variables (components) accounting for as much as possible of the variance in multivariate data (Davis, 1986; Harper, 1999) that are linear combinations of original variables (Hammer et al., 2001). The most important components are correlated with other underlying variables that in the case of ecological data can be a physical gradient (Hammer et al., 2001). The PCA usually allows assessing the eigenvalues and eigenvectors of the variance-covariance matrix or the correlation matrix. Our study case is represented by a dataset composed of variables measured in different units; so, we used the correlation method because this way the variables are automatically normalized by the program (Hammer et al., 2001). The tool also allows estimating the percentages of variance accounted for by the principal components. The analysis is usually significant when the variance is accounted for by the first one or two components (Hammer et al., 2001). In some cases, our results are also coherent for the third component because the component can clearly be linked to a particular oceanographic feature.

In addition, spectral analysis was performed using the REDFIT tool implemented in the PAST software (Hammer et al., 2001). We re-analyzed data previously explored by Palumbo et al. (2013b) for MIS 11 using a setting aimed at more details in the higher frequency range (e.g., periodicities of 5-6 kyr). The same setting was then applied to the MIS 1 coccolith and the alkenone data of both periods, for which a frequency analysis is presented for the first time. The program REDFIT allows analyzing unevenly sampled time series and selecting the number of oversampling and segments to optimize the output of the power spectra. In order to overcome the continuous decrease of spectral amplitude with increasing frequency, typical of paleoclimate dataset, the program allows to apply a first-order autoregressive (AR1) process ("red noise"; Schulz and Mudelsee, 2002). In addition, the spectral significance of the peaks, depending on the segment length (Thomson, 1990), is estimated selecting "critical" false-alarm levels relatively to a fixed set of false-alarm levels (Schulz and Mudelsee, 2002). In our analyses, we set the false-alarm levels to $90 \%$ and $95 \%$ (corresponding to $\chi^{2} 90 \%$ and $\chi^{2} 95 \%$ ), respectively, and considered as significant from a paleoceanographic point of view- only those peaks reaching the $95 \%$ level or higher. Finally, the bandwidth (BW), indicating the spectral resolution given as the width between the $-6 \mathrm{~dB}$ 
points (Schulz and Mudelsee, 2002), is 0.080 and 0.021 for the MIS 1 and MIS 11 intervals, respectively.

\section{Results}

\subsection{Alignments of Marine Isotope Stages: Coccolithophore assemblages and alkenone data}

The SST curves of both MIS 11 and MIS 1 support the two alignment options (Fig. 2). The deglaciation option aligns the two sharp SST decreases, although the SST reached lower values during MIS 12. Following the precession alignment, the Holocene SST record overlaps with the second MIS 11c SST plateau starting at $410 \mathrm{ka}$, with both records showing comparable maximum values of $17-18^{\circ} \mathrm{C}$ and a long-term declining trend.

Figures 3 and 4 summarize and compare the most relevant coccolith and alkenone data for the two intervals. Between 445 and 441 ka, i.e., during MIS 12, the NAR of small Gephyrocapsa reached maximum values in the order of $\mathrm{e}^{+10}$ before declining, whereas total NAR were significantly higher between 23 and $19 \mathrm{ka} \mathrm{BP}$, i.e., during MIS 2, with values in the order of $\mathrm{e}^{+11}$ (Fig. 3). During the same periods, the SST show comparable values of about $15^{\circ} \mathrm{C}$ (Fig. 2). The intervals $440 \mathrm{ka}-427 \mathrm{ka}$ and 18-15 ka BP were both marked by highest values of $C$. pelagicus ssp. pelagicus and of $\mathrm{C}_{37: 4} \%$ and the lowest values of total NAR and small Gephyrocapsa accumulation rate (Fig. 3). Between 425 and $409 \mathrm{ka}$ increased percentage values of $U$. sibogae and C. pelagicus ssp. azorinus are observed that are comparable to those recorded between 12 and $7 \mathrm{kyr}$ BP, although C. pelagicus ssp. pelagicus percentages show frequent peaks during the latter phase, which are not recorded during MIS 11c.

\subsection{Principal Component Analysis (PCA)}

PCA was used in this study to evaluate the correlation among several variables. The PCA results for the complete time series and the interglacial and deglacial intervals of each period, respectively, are shown in Figures 5, 6 and 7. The PCA of the last 24 kyr BP interval (Fig. 5A, B), performed on $\mathrm{SST}, \% \mathrm{C}_{37: 4}, \%$. pelagicus ssp. pelagicus, $\% U$. sibogae, and the small Gephyrocapsa accumulation rate, reveals that $48 \%$ of the variance is represented by principal component (pco) 1, 26\% by pco 2 and $15 \%$ by pco3. The scatter diagrams of pco 1 vs. pco 2 and pco3 vs. pco1, respectively, display similar influences for SST and \%U. sibogae and for $\%$. pelagicus ssp. pelagicus and $\% \mathrm{C}_{37: 4}$ (Fig. 5A), but an independent influence for the small Gephyrocapsa accumulation rate within the 95\% ellipse (Fig. 5B). For the 445-360 ka interval, the PCA (Fig. 5C, D) reveals that $42 \%$ of the variance is represented by pco1, $21 \%$ by pco 2 and $16 \%$ by pco3, a total of $79 \%$. Minor variance percentages are indicated for pco4 and pco5. The pco1 vs. pco2 scatter 
diagram shows independent influences for SST and small Gephyrocapsa accumulation rate, whereas similar influences are exposed for $\%$. pelagicus ssp. pelagicus and $\% \mathrm{C}_{37: 4}$ within the $95 \%$ ellipse (Fig. 5C). The pco1 vs. pco3 scatter diagram displays similar influences for SST and \%U. sibogae (Fig. 5D).

The PCA performed for the deglacial interval from 19 to $13.5 \mathrm{kyr}$ BP (Fig. 6A) for the parameters of small Gephyrocapsa accumulation rate, \%U. sibogae, SST, \%C. pelagicus ssp. pelagicus, and $\% \mathrm{C}_{37: 4}$ shows $43 \%$ of variance for pco1 and $27 \%$ for pco 2 . The pco1 vs. pco 2 scatter diagram indicates similar influences for SST and \%U. sibogae and for $\%$ C. pelagicus ssp. pelagicus and $\% \mathrm{C}_{37: 4}$ (Fig. 6A). An independent behavior is revealed for the small Gephyrocapsa accumulation rate (Fig. 6A). The PCA performed on the same proxies for the interval 430-425 kyr (MIS 12 deglaciation; Fig. 6B) results in 49\% of variance for pco1 and 20\% for pco2. Independent behaviors are observed for all the proxies (Fig. 6B)

For the early interglacial MIS 1 interval of 12 to $7 \mathrm{kyr}$ BP, the PCA (Fig. 7A) performed on the small Gephyrocapsa accumulation rate, \%U. sibogae and SST (excluding \%C. pelagicus ssp. pelagicus and $\% \mathrm{C}_{37: 4}$ because of low variability) discloses $49 \%$ of variance for pcol and $30 \%$ for pco2. The pco1 vs. pco2 scatter diagram shows similar influences for SST and \%U. sibogae and an independent behavior for the small Gephyrocapsa accumulation rate (Fig. 7A). PCA performed on the same proxies for the interval 409-402 kyr (Fig. 7B) indicate 62\% of variance for pcol and $29 \%$ for pco2 and the pco1 vs. pco2 scatter diagram reveals independent influences for all the proxies (Fig. 7B).

\subsection{Spectral Analysis}

The spectral analyses results for the last 24 kyr BP interval (Fig. 8), reveal significant cycles close to 5-6 kyr in the records of the small Gephyrocapsa absolute abundance (\#coccoliths/g of sediment; Fig. 8A), sum of cold species (Fig. 8B) and the \%C. pelagicus spp. azorinus (Fig. 8E). These periods are also observed in the \%U. sibogae periodogram (Fig. 8D), although with a lower significance (reaching 90-95\% significance levels). These cycles are not seen at significant levels in the \%C. pelagicus ssp. pelagicus power spectrum (Fig. 8C).

For the 445-360 kyr interval, the power spectra for the small Gephyrocapsa accumulation rate, \%U. sibogae and SST reveal cycles close to 10-11 kyr in addition to the 5-6 kyr cycles (Fig. $8 \mathrm{~A}, \mathrm{C}$ and $\mathrm{D})$. For the $\% \mathrm{C}_{37: 4}$ periodogram, these cycles are present with a lower significance (reaching 90-95\% significance levels; Fig. 8B). 


\section{Discussion}

\subsection{Indications from the extended time intervals}

The PCA results allow to distinguish between the three, main surface-ocean regimes that influenced coccolithophores on the Iberian Margin. During both the MIS 11-MIS 12 and MIS 1MIS 2 intervals, the first three pco's are sufficient to explain the coccolithophores' characteristics in terms of prevailing SST and nutrient conditions. For the MIS 11-MIS 12 period (Fig. 5C, D), the first two components are related to the nutrient-rich, temperate-warm Portugal Current and to the subpolar waters regime that is portrayed as cold and less adequate for the development of coccolithophores (Fig. 5C). The third pco is connected to the Iberian Poleward Current regime, which at that time is characterized by warm surface waters with no particular relevance to nutrient concentrations (Fig. 5D). In the case of the MIS 1-MIS 2 interval, the first three pco's represent $90 \%$ of variance (Fig. 5A, B). There, the first two components are linked to the subpolar and Iberian Poleward Current regimes, the latter of the two currents probably transported warm and, in contrast to MIS 11, oligotrophic waters (Fig. 5A). The third pco identifies the Portugal Current regime (Fig. 5B). As indicated by the coccolith and alkenone data (Fig. 3), the Portugal Current and the subpolar waters show similar characteristics during both MIS 11 and MIS 1. The Iberian Poleward Current, on the other hand, appears to transport different kinds of waters, distinguished mainly in terms of nutrient availability, i.e. being more mesotrophic during MIS 11 as reflected in the lower abundances of $U$. sibogae and $F$. profunda and fewer appearances of $C$. pelagicus azorinus than during MIS 1 (Fig. 4).

\subsection{Deglaciations}

The most common, extreme events recognized at the Iberian margin during the deglaciations are significant SST minima (Fig. 2; Rodrigues et al., 2017), which in core MD03-2699 are also marked by a $\% \mathrm{C}_{37: 4}$ increase indicating less saline surface waters, a decline in coccolithophore productivity and increased percentages of Coccolithus pelagicus ssp. pelagicus (Fig. 3) (Rodrigues et al., 2010; 2011; Amore et al., 2012; Palumbo et al., 2013a, b). During the transition from MIS 12 to MIS 11 (Heinrich-type event 4) and during the interval 18-15 ka BP (Greenland stadial 2a/Heinrich event 1), the Iberian margin was thus characterized by the arrival of cold, fresh surface waters of subpolar origin, which, together with a less intense Portugal Current and reduced wind strength, hampered coccolithophore productivity (Amore et al., 2012; Rodrigues et al., 2011; Palumbo et al., 2013b; Marino et al., 2014).

Directly comparing the two deglaciation intervals (Fig. 3) highlights that the period of low paleoproductivity during MIS 12 lasted significantly longer (440-427 ka) than Heinrich-type event 
4 and thus also longer than the corresponding period during the MIS 2 deglaciation, i.e. Heinrich event 1 . Just prior to the arrival of the subpolar waters, the Iberian margin experienced increased paleoproductivity with Portugal Current persistence during MIS 12 and MIS 2 (Amore et al., 2012; Palumbo et al., 2013a, b). However, comparing the paleoproductivity records during the two glacials, reveals some differences in the Portugal Current dynamics as indicated by the order of magnitude difference in the values of the paleoproductivity proxies (Fig. 3). The Portugal Current and associated upwelling regime were more intense during the last glacial maximum than during late MIS 12. Nevertheless, SST values (Fig. 2) were quite comparable during both periods (values close to $15^{\circ} \mathrm{C}$ ), suggesting that the main difference cannot be associated with a response of coccolithophores to different temperature ranges but more likely to higher nutrient availability during MIS 2 than MIS 12, which, at the studied site, is nowadays caused by stronger westerly winds and upwelling intensity (Ríos et al., 1992; Fiúza et al., 1998; Pérez et al., 2001; Coelho et al., 2002; Peliz et al., 2005; Relvas et al., 2007). In fact, the PCA reveals that during both intervals, i.e. 19-13.5 kyr BP (Fig. 6A) and 430-425 kyr (Fig. 6B), the paleoproductivity increase occurred during warming phases, whereas the subpolar waters were clearly characterized by low SST and less adequate conditions for coccolithophore proliferation.

In addition, the oceanographic signal indicated by the PCA (Fig. 6A, B) during both deglaciations suggests that the two main components, representing $70 \%$ and $79 \%$ of variance, respectively, are enough to explain the surface-ocean signals. The pco1 vs. pco2 scatter diagram for the interval 19-13.5 kyr BP (Fig. 6A) can be interpreted as function of temperature and nutrient availability allowing to distinguish clearly the three, main surface-ocean regimes affecting the Iberian margin during this interval, i.e. the Portugal Current, the Iberian Poleward Current and the subpolar waters. The pco1 vs. pco2 scatter diagram for the MIS 12 deglaciation (Fig. 6B), on the other hand, can be interpreted as function of temperature and subpolar waters with no distinct nutrient signature.

Despite apparently different wind and thus upwelling strengths, surface-ocean dynamics evolved quite similarly during both periods. The Portugal Current persistence at the beginning of the interval was substituted by the arrival of subpolar waters followed by a gradual SST increase associated with a period of higher surface instability. In fact, during the onsets of both MIS 11 and MIS 1, i.e., during the early interglacial phase, the site was affected by the Iberian Poleward Current and sometimes even the Azores Current (Fig. 4). The subtropical water influence alternated with periods of Portugal Current prevalence and decreasing persistence of subpolar waters. The PCA result (Fig. 6A), however, reveals that during the MIS 2 deglaciation the Iberian Poleward Current transported warm, nutrient-poor surface waters, as shown by the co-occurrence of $U$. sibogae with 
high SST and low nutrient availability. During the MIS 12 deglaciation, on the other hand, the PCA (Fig. 6B) indicates $U$. sibogae coinciding with medium levels of SST and nutrient availability, suggesting that the Iberian Poleward Current transported warm-temperate, mesotrophic surface waters. The hypothesis of more oligotrophy during the MIS 2 deglaciation is also supported by the more frequent and generally more abundant presence of $F$. profunda, a species which is considered to live in stratified surface waters (e.g., Molfino and McIntyre, 1990) (Fig. 4).

\subsection{MIS 11c vs. early-to-mid Holocene}

In the case of aligning the deglaciations, the early-to-mid Holocene (12 - $7 \mathrm{kyr}$ BP) does not show a clear analogy with early MIS 11 (425 - 409 kyr) both in terms of mean SST values and surface-ocean dynamics (Fig. 2). In fact, the early MIS 11 was characterized by mean SST values of $<18^{\circ} \mathrm{C}$, whereas the early-to-mid Holocene experienced mean values $>18^{\circ} \mathrm{C}$ (Rodrigues et al., 2011; Rodrigues et al., 2010). The early MIS 11 period was marked by Portugal Current prevalence and the upwelled waters were replenished by ENACWst (Palumbo et al., 2013a). In contrast, the Iberian margin was affected mainly by the Iberian Poleward Current during the early-to-mid Holocene (Palumbo et al., 2013b), in agreement with coccolithophore and planktonic foraminifera evidence from the southern and southwestern Iberian margin (e.g., Colmenero-Hidalgo et al., 2004; Salgueiro et al., 2014). The best analogy is reached by comparing the early-to-mid Holocene with the peak interglacial period of MIS 11c (409 - 402 kyr), following the precession alignment criterion (Fig. 2). The SST show comparable mean values around $18^{\circ} \mathrm{C}$ and coccolithophore productivity in both intervals was low, which, in combination with the higher values of $U$. sibogae (Fig. 4), suggests the prevalence of the Iberian Poleward Current. The presence of C. pelagicus ssp. azorinus indicates that the Azores Current contributed significantly to the Iberian Poleward Current during short episodes (Fig. 4). Both U. sibogae and C. pelagicus ssp. azorinus show maximum percentages during MIS $11 \mathrm{c}$, but lower than the values reached during early MIS 1. F. profunda also displays higher percentages during early MIS 1 than during MIS 11c (Fig. 4). All these evidences suggest a stronger Iberian Poleward Current and ENACWst influence leading to stronger stratification during the early-to-mid Holocene. In fact, the PCA (Fig. 7A, B) indicates that the Iberian Poleward Current transported oligotrophic, warm/subtropical waters during the early-to-mid Holocene to the study site, whereas the advected waters were more temperate-warm and mesotrophic during MIS 11c.

For the evaluation of the best analog alignment, it is important to comprehend what might have caused the different Iberian Poleward Current properties during the two interglacial periods. Variance in the properties could be related to a different position and/or strengthening of the Azores High as a consequence of two different positions of the Inter-Tropical Convergence Zone (ITCZ). 
Pervasive relatively warm conditions off SW Iberia may reflect the persistent dominance of the subtropical Azores and Iberian Poleward Currents in this area during the final phase of MIS 11c (Voelker et al., 2010), even after the onset of the northern hemisphere ice sheet growth at $\sim 400 \mathrm{ka}$ (e.g., Oliveira et al., 2016). During both, MIS 11c and the Holocene, the ITCZ moved northward causing a weakening of westerly winds. The ITCZ's position was, however, more southern during MIS 11c relative to the early Holocene (e.g., Kandiano et al., 2012) leading probably to the heattransport changes within the Iberian Poleward Current. A possible role also of NAO negative-like modes was hypothesized in the general atmospheric setting of MIS 11c (Kandiano et al., 2012). If we consider that negative modes of NAO are nowadays associated to a possible intensification of the Iberian Poleward Current (Sánchez et al., 2007), its intensification during MIS 11c could in effect also be related to similar modes occurring at millennial-scale. Moreover, during the early-tomid Holocene, between 8.2 and $7 \mathrm{ka} \mathrm{BP}$, the wettest and warmest conditions and indication for NAO variability in terms of higher/lower persistence of the index were documented in southern Spain (Jiménez-Moreno and Anderson, 2012). Regarding the role of NAO+/- modes on the earlyto-mid Holocene Azores High/Icelandic Low position, controversial results from paleoclimatic archives have been documented in the last years (Gladstone et al., 2005; Wanner, 2008; Olsen et al., 2012; Morley et al., 2014; Wassenburg et al., 2016), although these patterns do not seem to be a dominant forcing for North Atlantic variability at that time (Repschläger et al., 2017). At the transition from the early to the mid-Holocene, changes in the wind direction could be related to a northward movement of the westerlies (thus their weakening) indicating a northward movement of the Azores High /Icelandic Low cells (Repschläger et al., 2017). We speculate that the possible analogy even so observed in our records could be due to similar mechanisms acting on the atmospheric-surface ocean settings.

In addition, throughout the Holocene, U. sibogae and paleoproductivity show alternating peaks implying oscillations in the dominant surface-water currents occurring at millennial timescale, as also proposed for MIS 11 (Palumbo et al., 2013b). The PCA results (Fig. 7) suggest that the first two pco's are enough to explain the two different regimes related to the Portugal and Iberian Poleward Currents, both during the early Holocene and during MIS 11c, confirming a possible Portugal Current prevalence with a general lower amplitude than the Iberian Poleward Current. The Portugal Current, however, exhibits different surface-water characteristics off the Iberian margin. During MIS 11c, the Portugal Current transported nutrient-rich, temperate-warm surface waters, whereas during the early Holocene this current transported more likely cool, nutrient-rich waters. Thus, even if the mean SST values are quite similar, suggesting a similar warming, the two main currents affecting the Iberian margin had distinct characteristics. 
Although the main signal is represented by the prevalence of the Iberian Poleward Current in both stages, the Iberian margin experienced incursions of colder surface waters during the early to mid-Holocene (Palumbo et al., 2013a; Salgueiro et al., 2014) that did not occur during MIS 11c. The near absence of $C$. pelagicus ssp. pelagicus and the $\% \mathrm{C}_{37: 4}$ values during MIS $11 \mathrm{c}$ (Palumbo et al., 2013b; Rodrigues et al., 2011) suggest that the Iberian margin was reached by subpolar waters only during the early Holocene when both of these indicators were observed (Palumbo et al, 2013a). So, our hypothesis is that MIS 11c was, from a paleoceanographic point of view, a more stable period than the early Holocene on the Iberian margin. Pollen data from several European continental records and SST records from the North Atlantic document the occurrence of abrupt events at 410/412 $\mathrm{ka}$ and $404 \mathrm{ka}$, which are related to changes in precipitation or short-term cooling, respectively (e.g., Rodrigues et al., 2011; Koutsodendris et al., 2012; Candy et al., 2014; Kandiano et al., 2017). The variability within MIS 11c was, in fact, more likely associated to a 8.2 ka-type cooling event (e.g., Koutsodendris et al., 2012; Candy et al., 2014). On the other hand, an exceptional event, recognized in the MD03-2699 sediments between 405 and $401 \mathrm{kyr}$, was probably related to increased river runoff driven by increased precipitation, but lagging evidences of cooling (Palumbo et al., 2013b). Surface-ocean dynamics were not affected as strongly by this variability as the continental climate or coccolithophores and alkenones were not sensitive enough to detect this event, in contrast to the one occurring in the early Holocene.

\subsection{Role of half and fourth precession cycles}

The length of the time window for the last $24 \mathrm{ka}$ BP does not allow investigating full precession cycles, so for this interval we focused only on their half and fourth components characterized by typical periodicity of 10-11 kyr and 5-6 kyr, respectively, as documented by Berger et al. (2006). Regarding to MIS 11, the spectral analysis of the small Gephyrocapsa accumulation rate shows the influence on paleoproductivity of full precession cycles but also a possible correlation with its half component (Fig. 9A). The spectral analysis of the U. sibogae percentages record indicates the presence of full and fourth harmonic precessional cycles suggesting their role in driving Iberian Poleward Current changes (Fig. 9D). The SST record also reveals an interesting, significant signal in the range of the half-precession cycles (Fig. 9C). The possible role of full precession cycles during the Middle Pleistocene in driving surface-ocean dynamics off the Iberian margin, via their influence on Portugal/ Iberian Poleward Current fluctuations, was previously documented (Amore et al., 2012; Palumbo et al., 2013b) as well as the influence of half and fourth precession components during the transition from MIS 12 to MIS 11 (Palumbo et al., 2013b). 
The presence of half and fourth precession cycles was predicted in the Equator insolation by Berger et al. (2006), but subsequent studies documented the presence of these cycles also in mid-tohigh latitudes marine records (e.g., Weirauch et al., 2008; Ferretti et al., 2010; Amore et al., 2012; Hernández-Almeida et al., 2012; Palumbo et al., 2013b). It is not yet fully understood how marine proxy data at higher latitudes can record high frequency precession cycles within their power spectra. One idea is that mid-to-high latitudes surface-ocean dynamics were driven by changes in insolation at the Equator (Ferretti et al., 2010; Hernandez-Almeida et al., 2012; Palumbo et al., $2013 b$ ), even if it is still unclear what is exactly the driving mechanism.

Our spectral analysis results indicate that during MIS 11 changes in insolation at the Equator following fourth precession cycles caused variability in the Iberian Poleward Current and led to its intensification off the Iberian margin. In a similar way, half precession cycles via Equator insolation variability caused probably changes in Portugal Current intensification and SST variability. These cycles were also observed in the C. pelagicus ssp. azorinus power spectrum (Palumbo et al., 2013b) suggesting their possible impact also on the northward flowing branch of the Azores Current, i.e. the Iberian Poleward Current. Regarding the last 24 ka BP data, the fourth precession cycles via insolation at the Equator could be the mechanism behind the Iberian Poleward Current variability off western Iberia as also suggested by the U. sibogae power spectrum (Fig. 8D). The fourth component could also be the main forcing for Portugal Current variability and the northward recirculation of the Azores Current as indicated by the power spectra of the small Gephyrocapsa absolute abundance (\#/g of sediment) and C. pelagicus ssp. azorinus (Figs. 8A and 8E), respectively.

If we consider that the three major currents on the Iberian margin have the Gulf Stream as common source water, a potential transfer mechanism could be that insolation at lower latitudes (in this case the Gulf of Mexico/ Caribbean Sea) caused changes in the source waters of these currents, and as a consequence of oceanic feedbacks these cycles were indirectly recorded in our study area. At the mid (and high) latitudes, in fact, the equatorial currents do not affect the surface oceanography directly, but are linked through the currents arising from them. In addition, because the Iberian margin is under the direct influence of the westerlies controlling the upwelling, a possible influence of Equator insolation on variability in the main North Atlantic atmospheric pressure centers can be supposed.

The C. pelagicus ssp. pelagicus power spectra for both MIS 11 (Palumbo et al., 2013b) and MIS 1 (Fig. 7C) do not show the half and fourth precession cycles' frequencies. Thus, we can interpret these results as an evidence of equatorial insolation not influencing the arrival of subpolar waters at the Iberian margin. However, the power spectrum of the sum of cold species during the 
MIS 1 interval (Fig. 8B) reveals the presence of fourth precession cycles suggesting their role on the arrival of colder surface waters but not of pure subpolar origin. The most abundant cold species recorded in this interval is represented by Gephyrocapsa muellerae (Palumbo et al., 2013a), which, near the Azores, was used as proxy for the influence of the North Atlantic Transitional Waters during the last $16 \mathrm{kyr}$ BP (Schwab et al., 2012). Our hypothesis is that the North Atlantic Transitional Waters recorded the influence of Equator insolation changes driven by fourth precession cycles as consequence of changes in the North Atlantic, Portugal and Azores Currents.

It is also interesting to note that the $\% \mathrm{C}_{37: 4}$ time series for the complete MIS 11 - MIS12 interval incorporates significant spectral power close to the periodicities of half and fourth precession components (Fig. 9B). These results suggest that advection of meltwaters was also linked to changes in Equator insolation, potentially via atmosphere-ocean feedbacks at high latitudes. The insolation feedback most likely acted as deteriorating factor on the ice sheets (e.g., Ruddiman, 2003) and their ice shelf extension, causing, in the end, the arrival of their meltwaters at the studied site.

\section{Summary and Conclusions}

In this study, we compared MIS 11 and MIS 1 coccolithophore and alkenone derived records from core MD03-2699 located on the Iberian margin to search for possible analogies in the temporal evolution of the surface-ocean dynamics. Considering that MIS 11 was an exceptional long interglacial, it is impossible to compare the full interval with entire Holocene trend. So, we opted to compare the records following two main alignment criteria: 1) aligning the deglaciations on the basis of MD03-2699 SST records and 2) aligning based on the precession cycles. We applied PCA to the data with the aim to distinguish possible differences or analogies between the characteristics of the surface water masses affecting the site, in particular in regard to SST and nutrient availability. When aligning the deglaciations, both MIS 12 and MIS 2 experienced the same surface-ocean evolution, namely a productive period being interrupted by the arrival of subpolar waters and then followed by variable conditions during the transition into full interglacial conditions. Even if the general evolutions were similar, the direct comparison highlighted that during the productive periods upwelling was stronger during MIS 2, thereby providing more nutrients for the coccolithophore community. The period of instability at the onset of the interglacials was marked by the reoccurring presence of the Iberian Poleward Current, sometimes with significant contributions from the Azores Current. When applying the precession cycle alignment, our records show the best analogy between early-to-mid Holocene and MIS11c. Also, these periods were characterized by the persistent presence of the Iberian Poleward Current, along 
with ENACWst. However, the MIS 11c subtropical surface waters were poorer in nutrients (mesotrophic) than their more oligotrophic MIS 1 counterparts. Another important observation that arose from comparing the two interglacial periods is related to the sporadic advection of cold, subpolar surface waters to the Iberian margin. Arrival of such waters was more relevant and frequent during the early-to-mid Holocene than during MIS 11c. Thus, despite the general similarities neither alignment results in exactly the same evolution in the prevailing surface-water masses. So, in conclusion, a compromise between the two solutions proposed here would be the best solution when comparing MIS 1 and MIS 11.

Even if during eccentricity minima stages, precession is typically characterized by weak variations (Hilgen et al., 1995, 2003; Zeeden et al., 2013), as it is the case for MIS 11 and MIS 1, our data suggest that this orbital parameter played an important role in surface-ocean dynamics on the Iberian margin. Because of the high resolution of our time series, we could investigate not only the full precession cycles during MIS 11, but also their higher frequency components during both MIS providing additional information on possible analogies/differences of these two crucial stages. From our point of view, it would be interesting to extend the current study to other sites within the North Atlantic's subtropical gyre in order to better understand possible relationships between the main currents and potential influences of the higher frequency precession cycles on the water mass properties and plankton communities.

\section{Acknowledgements}

For the initial work, E. Palumbo was supported by $\mathrm{Ph}$. D. grants provided by MIUR (Ministero dell'Istruzione, dell'Università e della Ricerca). F. O. Amore received financial aid from FRA grants AMORE2013 and AMORE2014. A. Voelker acknowledges financial support from the Fundação para a Ciencia e a Tecnologia (FCT) in form of the PORTO project (PDCT/MAR/58282/2004) and her FCT Investigador contract (IF/01500/2014). Recovery of core MD03-2699 during the Picabia cruise onboard the R/V Marion Dufresne (A.V.) was funded by a EU grant of Access to Research Infrastructure. We thank the two anonymous reviewers for their comments that helped to improve our manuscript.

\section{Data availability}

All proxy data is available from the PANGAEA data center:

0-24 ka coccoliths: https://doi.org/10.1594/PANGAEA.836238

0-24 ka alkenones: https://doi.org/10.1594/PANGAEA.761812 
360-445 ka coccoliths: https://doi.org/10.1594/PANGAEA.833636 and https://doi.org/10.1594/PANGAEA.836259; 360-445 ka alkenones: https://doi.org/10.1594/PANGAEA.761771

\section{References}

Amore, F. O., Flores, J.A., Voelker, A. H. L., Lebreiro, S. M., Palumbo, E., and Sierro, F. J., 2012. A Middle Pleistocene Northeast Atlantic Coccolithophore Record: Paleoclimatology and Paleoproductivity aspects. Marine Micropaleontology, 90-91, 44-59.

Antoine, P., Moncel, M. H., Limondin-Lozouet, N., Locht, J. L., Bahain, J. J., Moreno, D., Voinchet, P., Auguste, P., Stoetzel, E., Dabkowski, J., Bello, S. M., Parfitth, S. A., Tombret, O., and Hardy, B., 2016. Palaeoenvironment and dating of the Early Acheulean localities from the Somme River basin (Northern France): New discoveries from the High Terrace at Abbeville-Carrière Carpentier. Quaternary Science Reviews, 149, 338-371, doi: 10.1016/j.quascirev.2016.07.035.

Ausín, B., Zúñiga, D., Flores, J.A., Cavaleiro, C., Froján, M., Villacieros-Robineau, N., Alonso-Pérez, F., Arbones, B., Santos, C., de la Granda, F., G. Castro, C., Abrantes, F., Eglinton, T.I., and Salgueiro, E., 2018. Spatial and temporal variability in coccolithophore abundance and distribution in the NW Iberian coastal upwelling system. Biogeosciences 15, 245-262.

Ayling B. F., Chappell J., Gagan M. K., and McCulloch M. T., 2015. ENSO variability during MIS 11 (424-374 ka) from Tridacna gigas at Huon Peninsula, Papua New Guinea. Earth and Planetary Science Letters, 431 (1), 236-246, doi: 10.1016/j.eps1.2015.09.037.

Baumann, K.H., and Freitag, T., 2004. Pleistocene fluctuations in the northern Benguela Current system as revealed by coccolith assemblages, Marine Micropaleontology, 52 (1-4), 195215, doi: 10.1016/j.marmicro.2004.04.011.

Benardout G., 2015. Ostracod-based palaeotemperature reconstructions for MIS 11 human occupation at Beeches Pit, West Stow, Suffolk, UK. Journal of Archaeological Science, 54, 421425, doi: 10.1016/j.jas.2014.07.027.

Berger, A., M. F. Loutre, and Mélice, J. L., 2006. Equatorial insolation: from precession harmonics to eccentricity frequencies, Climate of the Past, 2, 131-136, doi: 10.5194/cp-2-131-2006.

Brand, L. E., 1994. Physiological ecology of marine coccolithophores, in, Coccolithophores, edited by Winter A., and W. Siesser, Cambridge University Press, Cambridge, pp. 39-49.

Bréhéret, J., 1978. Formes nouvelles quaternaires et actuelles de la famille des Gephyrocapsaceae (Coccolithophorides), Comptes Rendus Hebdomadaires des Séances de l'Academie des Sciences Paris, 287, 447-449. 
Bubenshchikova N., Nürnberg D., and Tiedemann R., 2015. Variations of Okhotsk Sea oxygen minimum zone: Comparison of foraminiferal and sedimentological records for latest MIS 12-11c and latest MIS 2-1. Marine Micropaleontology, 121, 52-69, doi: 10.1016/j.marmicro.2015.09.004.

Buckley, M. W., and Marshall, J., 2016. Observations, inferences, and mechanisms of Atlantic Meridional Overturning Circulation variability: A review. Rev. Geophys., 54, 5-63, doi:10.1002/2015RG000493.

Buzas, M. A., 1990. Another look at confidence limits for species proportions. Journal of Paleontology 64, 842-843.

Candy I., Schreve D. C., Sherriff J., and Tye G. J., 2014. Marine Isotope Stage 11: Palaeoclimates, palaeoenvironments and its role as an analogue for the current interglacial. EarthScience Reviews, 128, 18-51, doi:10.1016/j.earscirev.2013.09.006.

Cheng, H., Edwards, R.L., Sinha, A., Spötl, C., Yi, L., Chen, S., Kelly, M., Kathayat, G., Wang, X., Li, X., Kong, X., Wang, Y., Ning, Y., and Zhang, H., 2016. The Asian monsoon over the past 640,000 years and ice age terminations. Nature 534, 640-646.

Coelho, H.S., R. J. J. Neves, M. White, P. C. Leitão, and A. J. Santos, 2002. A model for ocean circulation on the Iberian coast. Journal of Marine Systems, 32 (3-4), 153-179.

Colmenero-Hidalgo, E., Flores, J. A., Sierro, F. J., Barcena, M. A., Löwemark, L., Schönfeld, J., and Grimalt, J. O., 2004. Ocean-surface water response to short-term climate changes revealed by coccolithophores from the Gulf of Cadiz (NE Atlantic) and Alboran Sea (W Mediterranean). Paleogeography Paleoclimatology Paleoecology, 205 (3-4), 317-336, doi: 10.1016/j.palaeo.2003.12.014.

D'Anjou, R.M., Wei, J.H., Castañeda, I.S., Brigham-Grette, J., Petsch, S.T., and Finkelstein, D.B., 2013. High-latitude environmental change during MIS 9 and 11: biogeochemical evidence from Lake El'gygytgyn, Far East Russia. Clim. Past 9, 567-581.

Davis, J.C., 1986. Statistics and Data Analysis in Geology. John Wiley \& Sons, 639 p.

Dickson, A.J., Leng, M.J., Maslin, M.A., Sloane, H.J., Green, J., Bendle, J.A., McClymont, E.L., and Pancost, R.D., 2010. Atlantic overturning circulation and Agulhas leakage influences on southeast Atlantic upper ocean hydrography during marine isotope stage 11. Paleoceanography, 25(3), PA3208, doi: 10.1029/2009pa001830.

Emanuele D., Ferretti P., Palumbo E., and Amore F. O., 2015. Sea-surface dynamics and palaeoenvironmental changes in the North Atlantic Ocean (IODP Site U1313) during Marine Isotope Stage 19 inferred from coccolithophore assemblages. Palaeogeography, Palaeoclimatology, Palaeoecology, 430, 104-117, doi: 10.1016/j.palaeo.2015.04.014. 
EPICA Community Members. Eight glacial cycles from an Antarctic ice core. Nature, 429, 623-628, doi: 10.1038/nature02599.

Eynaud, F., de Abreu, L., Voelker, A., Schönfeld, J., Salgueiro, E., Turon, J. L., Penaud, A., Toucanne, S., Naughton, F., Sánchez Goñi, M. F., Malaizé, B., and Cacho, I., 2009. Position of the Polar Front along the western Iberian margin during key cold episodes of the last $45 \mathrm{ka}$. Geochem. Geophys. Geosyst., 10, Q07U05, doi: 10.1029/2009GC002398

Fawcett, P.J., Werne, J.P., Anderson, R.S., Heikoop, J.M., Brown, E.T., Berke, M.A., Smith, S.J., Goff, F., Donohoo-Hurley, L., Cisneros-Dozal, L.M., Schouten, S., Sinninghe Damste, J.S., Huang, Y., Toney, J., Fessenden, J., WoldeGabriel, G., Atudorei, V., Geissman, J.W., and Allen, C.D., 2011. Extended megadroughts in the southwestern United States during Pleistocene interglacials. Nature 470, 518-521.

Ferretti P., Crowhurst S. J., Naafs B. D. A., and Barbante C., 2015. The Marine Isotope Stage 19 in the mid-latitude North Atlantic Ocean: astronomical signature and intra-interglacial variability. Quaternary Science Reviews, 108, 95-110, doi: 10.1016/j.quascirev.2014.10.024.

Ferretti, P., Crowhurst, S. J., Hall, M. A., and Cacho, I., 2010. North Atlantic millennialscale variability 910 to $790 \mathrm{ka}$ and the role of the equatorial insolation forcing. Earth, and Planetary Science Letters, 293 (1-2), 28-41, doi: 10.1016/j.eps1.2010.02.016.

Fiuza, A. F. G., Hamann, M., Ambar, I., Díaz del Río, G., González, N., and Cabanas, J. M., 1998. Water masses and their circulation off western Iberia during May 1993. Deep Sea Research I, 45 (7), 1127-1160, doi: 10.1016/S0967-0637(98)00008-9.

Flores, J. A., and Sierro F. J., 1997. Revised technique for calculation of calcareous nannofossils accumulation rates. Micropaleonology, 43 (3), 321-324.

Flores, J. A., Sierro, F. J., Frances, G., Vazquez, A., and Zamarreno, I., 1997. The last 100,00 years in the western Mediterranean: sea surface water and frontal dynamics as revealed by coccolithophores. Marine Micropaleontology 29, 351-366.

Flores, J.A., Gersonde, R., Sierro, F.J., 1999. Pleistocene fluctuations in the Agulhas Current Retroflection based on the calcareous plankton record. Marine Micropaleontology, 37(1), 1-22. doi: 10.1016/S0377-8398(99)00012-2.

Flores, J.-A., Marino, M., Sierro, F.J., Hodell, D.A. and Charles, C.D., 2003. Calcareous plankton dissolution pattern and coccolithophore assemblages during the last $600 \mathrm{kyr}$ at ODP Site 1089 (Cape Basin, South Atlantic): paleoceanographic implications. Palaeogeography, Palaeoclimatology, Palaeoecology, 196(3-4), 409-426.

Flores, J. A, Colmenero-Hidalgo, E., Mejia-Molina, A. E., Baumann, K.-H., Henderiks, J., Larsson, K., Prabhu, C. N., Sierro, F. J., and Rodrigues, T., 2010. Distribution of large Emiliania 
huxleyi in the Central and Northeast Atlantic as a tracer of surface ocean dynamics during the last 25,000 years. Marine Micropaleontology, 76 (3-4), 53-66, doi: 10.1016/j.marmicro.2010.05.001.

Gladstone, R. M., Ross, I., Valdes, P. J., Abe-Ouchi, A., Braconnot, P., Brewer, S., Kageyama, M., Kitoh, A., Legrande, A., Marti, O., Ohgaito, R., Otto-Bliesner, B., Peltier, W. R., and Vettoretti, G., 2005. Mid-Holocene NAO: A PMIP2 model intercomparison. Geophysical Research Letters, 32, L16707, doi:10.1029/2005GL023596.

Guerreiro, C.V., Baumann, K.H., Brummer, G.J.A., Fischer, G., Korte, L.F., Merkel, U., Sá, C., de Stigter, H., and Stuut, J.B.W., 2017. Coccolithophore fluxes in the open tropical North Atlantic: influence of thermocline depth, Amazon water, and Saharan dust. Biogeosciences 14, 4577-4599.

Hammer, Ø., Harper, D.A.T., Ryan, P.D., 2001. PAST - Palaeontological Statistics. http://www.toyen.uio.no/ ohammer/past.

Harper, D.A.T. (ed.)., 1999. Numerical Palaeobiology. John Wiley \& Sons, 468 p.

Hernández-Almeida, I., Sierro, F. J., Cacho, I., Flores, J. A., 2012. Impact of suborbital climate changes in the North Atlantic on ice sheet dynamics at the Mid-Pleistocene Transition. Paleoceanography, 27, PA3214, doi:10.1029/2011PA002209.

Hilgen, F. J., Abdul Aziz, H., Krijgsman, W., Raffi, I., and Turco, E., 2003. Integrated stratigraphy and astronomical tuning of the Serravallian and lower Tortonian at Monte dei Corvi (Middle-Upper Miocene, northern Italy). Palaeogeography, Palaeoclimatology, Palaeoecology, 199 (3-4): 229-264, doi: 10.1016/S0031-0182(03)00505-4.

Hilgen, F. J., Krijgsman, W., Langereis, C. G., Lourens, L. J., Santarelli, A., and Zachariasse, W.J., 1995. Extending the astronomical (polarity) time scale into the Miocene. Earth and Planetary Science Letters, 136 (3-4), 495-510, doi: 10.1016/0012-821X(95)00207-S.

Hodell, D. A., Charles, C. D., and Ninnemann, U. S., 2000. Comparison of interglacial stages in the South Atlantic sector of the Southern Ocean for the past $450 \mathrm{kyr}$ : implifications for Marine Isotope Stage (MIS) 11. Global and Planetary Change, 24(1), 7-26, doi: 10.1016/S09218181(99)00069-7.

Hodell, D., Crowhurst, S., Skinner, L., Tzedakis, P.C., Margari, V., Channell, J.E.T., Kamenov, G., Maclachlan, S., and Rothwell, G., 2013. Response of Iberian Margin sediments to orbital and suborbital forcing over the past 420 ka. Paleoceanography, 28, 185-199, doi:10.1002/palo.20017.

Hurrell, J. W., 1995. Decadal trends in the North Atlantic Oscillation: Regional temperatures and precipitation, Science, 269, 676-679, doi: 10.1126/science.269.5224.676. 
Hurrell, J. W., and Deser, C., 2010. North Atlantic climate variability: The role of the North Atlantic Oscillation. Journal of Marine Systems, 79(3-4), 231-244, doi: 10.1016/j.jmarsys.2009.11.002.

Jiménez-Moreno, G., and Anderson, R. S., 2012. Holocene vegetation and climate change recorded in alpine bog sediments from the Borreguiles de la Virgen, Sierra Nevada, southern Spain. Quaternary Research, 77(1), 44-53, doi: 10.1016/j.yqres.2011.09.006.

Kandiano E. S., Bauch H. A., Fahl K., Helmke J. P., Röhl U., Pérez-Folgado M., and Cacho I., 2012. The meridional temperature gradient in the eastern North Atlantic during MIS 11 and its link to the ocean-atmosphere system. Palaeogeography, Palaeoclimatology, Palaeoecology, 333334: 24-39, doi: 10.1016/j.palaeo.2012.03.005.

Kandiano, E.S., van der Meer, M.T.J., Schouten, S., Fahl, K., Sinninghe Damsté, J.S., Bauch, H.A., 2017. Response of the North Atlantic surface and intermediate ocean structure to climate warming of MIS 11. Scientific Reports, 7, 46192, doi: 10.1038/srep46192.

Klein, B., and Siedler, G., 1989. On the origin of the Azores Current. Journal of Geophysical Research, 94(C5), 6159-6168.

Koutsodendris, A. P,ross, J., Müller, U.C., Brauer, A., Fletcher, W.J., Kühl, N., Kirilova, E., Verhagen, F.T.M., Lücke, A., and Lotter, A.F., 2012. A short-term climate oscillation during the Holsteinian interglacial (MIS 11c): An analogy to the $8.2 \mathrm{ka}$ climatic event? Global and Planetary Change, 92-93, 224-235.

Lisiecki, L. E., and Raymo, M. E., 2005. A Pliocene-Pleistocene stack of 57 globally distributed benthic $\delta^{18} \mathrm{O}$ records. Paleoceanography, 20, PA1003, doi:10.1029/2004PA001071.

Lopez-Otalvaro, G. E., Flores, J. A., Sierro, F. J., and Cacho, I., 2008. Variations in Coccolithophorids production in the Eastern Equatorial Pacific at ODP Site 1240 over the last seven glacial-interglacial cycles. Marine Micropaleontology, 69(1), 52-69, doi: 10.1016/j.marmicro.2007.11.009

Loutre M. F., and Berger A., 2000. Future Climatic Changes: Are We Entering an Exceptionally Long Interglacial? Climatic Change, 46, 61-90, doi: 10.1023/A:1005559827189.

Loutre, M. F., 2003. Clues from MIS 11 to predict the future climate - a modelling point of view. Earth and Planetary Science Letters, 212(1-2), 213-224, doi:10.1016/S0012-821X(03)002358.

Loutre, M.F., and Berger, A., 2003. Marine Isotope Stage 11 as an analogue for the present interglacial. Global and Planetary Change, 36(3), 209-217, doi: 10.1016/S0921-8181(02)00186-8 
Maiorano, P., Marino, M., Balestra, B., Flores, J.-A., Hodell, D.A., and Rodrigues, T., 2015. Coccolithophore variability from the Shackleton Site (IODP Site U1385) through MIS 16-10. Global and Planetary Change, 133, 35-48, https://doi.org/10.1016/j.gloplacha.2015.07.009.

Margari, V., Skinner, L.C., Hodell, D.A., Martrat, B., Toucanne, S., Grimalt, J.O., Gibbard, P.L., Lunkka, J.P., and Tzedakis, P.C., 2014. Land-ocean changes on orbital and millennial time scales and the penultimate glaciation. Geology, 42, 183-186.

Marino, M., Maiorano, P., Tarantino, F., Voelker, A., Capotondi, L., Girone, A., Lirer, F., Flores, J.-A., and Naafs, B. D. A., 2014. Coccolithophores as proxy of seawater changes at orbitalto-millennial scale during middle Pleistocene Marine Isotope Stages 14-9 in North Atlantic core MD01-2446. Paleoceanography, 29, 518-532, doi:10.1002/2013PA002574.

Marino, M., Girone, A., Maiorano, P., Di Renzo, R., Piscitelli, A., and Flores, J.A., 2018. Calcareous plankton and the mid-Brunhes climate variability in the Alboran Sea (ODP Site 977). Palaeogeography, Palaeoclimatology, Palaeoecology, 508, 91-106, doi: 10.1016/j.palaeo.2018.07.023.

Martrat, B., Grimalt J. O., Shackleton N., de Abreu L., Hutterli M. A., and Stocker T. F., 2007. Four Climate Cycles of Recurring Deep and Surface Water Destabilizations on the Iberian Margin. Science, 317, 502-507, doi: 10.1126/science.1139994.

McIntyre, A., and Bè, A. H. W., 1967. Modern coccolithophores of the Atlantic Ocean-I. Placolith and cystoliths. Deep-Sea Research and Oceanographic Abstracts, 14(5), 561-597, doi: 10.1016/0011-7471(67)90065-4.

McManus, J., Oppo, D.W. and Cullen, J.L., 1999. A 0.5-million-year record of millennialscale climate variability in the North Atlantic. Science, 283, 971-975.

Milker, Y., Rachmayani, R., Weinkauf, M.F.G., Prange, M., Raitzsch, M., Schulz, M., and Kučera, M., 2013. Global and regional sea surface temperature trends during Marine Isotope Stage 11. Clim. Past 9, 2231-2252.

Moita, M.T., Silva, A., Palma, S., and Vilarinho, M.G., 2010. The coccolithophore summerautumn assemblage in the upwelling waters of Portugal: Patterns of mesoscale distribution (19852005). Estuarine, Coastal and Shelf Science 87, 411-419.

Molfino, B., and McIntyre, A. 1990. Nutricline variation in the equatorial Atlantic coincident with the Younger Dryas. Paleoceanography, 5, 997-1008.

Morley, A., Rosenthal, Y., and de Menocal, P., 2014. Ocean-atmosphere climate shift during the mid-to-late Holocene transition. Earth and Planetary Science Letters, 388, 18-26, doi: 10.1016/j.eps1.2013.11.039.

Okada, H., and McIntyre, A., 1979. Seasonal distribution of modern coccolithophores in the 
western North Atlantic Ocean. Marine Biology, 54, 319-328.

Oliveira, D., Desprat, S., Rodrigues, T., Naughton, F., Hodell, D., Trigo, R., Rufino, M., Lopes, C., Abrantes, F., and Sánchez Goñi, M. F., 2016. The complexity of millennial-scale variability in southwestern Europe during MIS 11. Quaternary Research, 86(3), 373-387, doi: 10.1016/j.yqres.2016.09.002.

Olsen, J., Anderson, N. J., and Knudsen, M. F., 2012. Variability of the North Atlantic Oscillation over the past 5,200 years. Nature Geoscience 5, 808-812, doi:10.1038/ngeo1589.

Palumbo, E., Flores, J.A., Perugia, C., Emanuele, D., Petrillo, Z., Rodrigues, T., Voelker, A.H.L., and Amore, F.O., 2013a. Abrupt variability of the last 24 ka recorded by coccolithophore assemblages off the Iberian Margin (core MD03-2699). Journal of Quaternary Science 28(3), 320328.

Palumbo, E., Flores, J.A., Perugia, C., Petrillo, Z., Voelker, A.H.L., and Amore, F.O., 2013b. Millennial scale Coccolithophore Paleoproductivity and surface water changes between 445 and $360 \mathrm{ka}$ (Marine Isotope Stages 12/11) in the Northeast Atlantic. Palaeogeography Palaeoclimatology Palaeoecology, 383-384, 27-41. doi:10.1016/j.palaeo.2013.04.024

Parente, A., Cachão, M., Baumann, K. H., de Abreu, L., and Ferreira, J., 2004. Morphometry of Coccolithus pelagicus s: 1. (Coccolithophore, Haptophyta) from offshore Portugal, during the last 200kyr. Micropaleontology, 50 (1), 107-120, doi: 10.2113/50.Suppl_1.107.

Past Interglacial Working Group of PAGES, 2016. Interglacials of the last 800,000 years. Reviews of Geophysics, 54, 162-219, doi:10.1002/2015RG000482.

Patterson, R.T. and Fishbein, E., 1989. Re-examination of the statistical methods used to determine the number of point counts needed for micropaleontological quantitative research. Journal of Paleontology 63, 245-248.

Peliz, A., Dubert, J., Santos, A.M.P., Oliveira, P.B. and Le Cann, B., 2005. Winter upper ocean circulation in the Western Iberian Basin - fronts, eddies and poleward flows: an overview. Deep Sea Research Part I: Oceanographic Research Papers 52, 621-646.

Pérez, F.F., Castro, C.G., Alvarez-Salgado, X.A., and Rios, A. F., 2001. Coupling between the Iberian basin - scale circulation and the Portugal boundary current system: a chemical study. Deep Sea Research Part I: Oceanographic Research Papers 48, 1519-1533.

Pol, K., Masson-Delmotte, V., Johnsen, S., Bigler, M., Cattani, O., Durand, G., Falourd, S., Jouzel, J., Minster, B., Parrenin, F., Ritz, C., Steen-Larsen, H.C., and Stenni, B., 2010. New MIS 19 EPICA Dome $\mathrm{C}$ high resolution deuterium data: Hints for a problematic preservation of climate variability at sub-millennial scale in the "oldest ice". Earth and Planetary Science Letters, 298(1-2), 95-103, doi: 10.1016/j.eps1.2010.07.030. 
Poulton, A.J., Holligan, P.M., Charalampopoulou, A., and Adey, T.R., 2017. Coccolithophore ecology in the tropical and subtropical Atlantic Ocean: New perspectives from the Atlantic meridional transect (AMT) programme. Progress in Oceanography 158, 150-170.

Regattieri, E., Giaccio, B., Galli, P., Nomade, S., Peronace, E., Messina, P., Sposato, A., Boschi, C., and Gemelli, M., 2016. A multi-proxy record of MIS 11-12 deglaciation and glacial MIS 12 instability from the Sulmona basin (central Italy). Quaternary Science Reviews, 132, 129145, doi: 10.1016/j.quascirev.2015.11.015.

Relvas, P., Barton, E.D., Dubert, J., et al. 2007. Physical oceanography of the western Iberia ecosystem: latest views and challenges. Progress in Oceanography 74, 149-173.

Repschläger, J., Garbe-Schönberg, D., Weinelt, M., and Schneider, R., 2017. Holocene evolution of the North Atlantic subsurface transport. Clim. Past, 13, 333-344, doi:10.5194/cp-13333-2017.

Reyes, A.V., Carlson, A.E., Beard, B.L., Hatfield, R.G., Stoner, J.S., Winsor, K., Welke, B., and Ullman, D.J., 2014. South Greenland ice-sheet collapse during Marine Isotope Stage 11. Nature $510,525-528$.

Rios, A., Pérez, F., and Fraga, F., 1992. Water masses in the upper and middle North Atlantic Ocean east of the Azores. Deep-Sea Research Part A. Oceanographic Research Papers, 39 (3-4), 645-658, doi: 10.1016/0198-0149(92)90093-9.

Rodrigues T., Grimalt J. O., Abrantes F., Naughton F., and Flores J. A., 2010. The last glacial-interglacial transition (LGIT) in the western mid-latitudes of the North Atlantic: Abrupt sea surface temperature change and sea level implications. Quaternary Science Reviews 29(15-16): 1853-1862.

Rodrigues, T., Alonso-García, M., Hodell, D.A., Rufino, M., Naughton, F., Grimalt, J.O., Voelker, A.H.L., and Abrantes, F., 2017. A 1-Ma record of sea surface temperature and extreme cooling events in the North Atlantic: A perspective from the Iberian Margin. Quaternary Science Reviews 172, 118-130.

Rodrigues, T., Voelker, A. H. L., Grimalt, J. O., Abrantes, F., Naughton, F., 2011. Iberian Margin sea surface temperature during MIS 15 to 9 (580-300 ka): Glacial suborbital variability versus interglacial stability. Paleoceanography, 26, PA1204, doi:10.1029/2010PA001927.

Rohling, E.J., Braun, K., Grant, K., Kucera, M., Roberts, A.P., Siddall, M., and Trommer, G., 2010. Comparison between Holocene and Marine Isotope Stage-11 sea-level histories. Earth and Planetary Science Letters, 291(1-4), 97-105, doi: 10.1016/j.epsl.2009.12.054.

Roth, P.H., 1994. Distribution of coccoliths in oceanic sediments. In: Winter, A., Siesser, W.G. (Eds.), Coccolithophores. Cambridge, University Press, Cambridge, pp. 199-218. 
Ruddiman, W.F., 2003. Orbital insolation, ice volume, and greenhouse gases. Quaternary Science Reviews 22, 1597-1629.

Saavedra-Pellitero, M., J. A. Flores, F. Lamy, F. J. Sierro, and A. Cortina, 2011. Coccolithophore estimates of paleotemperature and paleoproductivity changes in the southeast Pacific over the past 27 kyr. Paleoceanography, 26, PA1201, doi:10.1029/2009PA001824.

Saavedra-Pellitero, M., Baumann, K.-H., Ullermann, J. and Lamy, F., 2017. Marine Isotope Stage 11 in the Pacific sector of the Southern Ocean; a coccolithophore perspective. Quaternary Science Reviews, 158, 1-14, doi: 10.1016/j.quascirev.2016.12.020.

Salgueiro E., Voelker A.H.L., de Abreu L., et al. 2010. Temperature and productivity changes off the western Iberian margin during the last $150 \mathrm{ky}$. Quaternary Science Reviews 29: 680-695.

Salgueiro, E., Naughton, F., Voelker, A.H.L., de Abreu, L., Alberto, A., Rossignol, L., Duprat, J., Magalhães, V.H., Vaqueiro, S., Turon, J.-L., and Abrantes, F., 2014. Past circulation along the western Iberian margin: a time slice vision from the Last Glacial to the Holocene. Quaternary Science Reviews, 106, 316-329, doi: 10.1016/j.quascirev.2014.09.001.

Sánchez R. F., Relvas P., and Delgado M., 2007. Coupled ocean wind and sea surface temperature patterns off the western Iberian Peninsula. Journal of Marine Systems 68, 103-127.

Sánchez-Goñi, M.F., Llave, E., Oliveira, D., Naughton, F., Desprat, S., Ducassou, E., Hodell, D. A., and Hernández-Molina, F.J., 2016. Climate changes in south western Iberia and Mediterranean Outflow variations during two contrasting cycles of the last 1Myrs: MIS 31-MIS 30 and MIS 12-MIS 11. Global and Planetary Change, 136, 18-29, doi: 10.1016/j.gloplacha.2015.11.006.

Schulz, M., and Mudelsee, M., 2002. REDFIT: estimating spectra directly from unevenly spaced paleoclimatic time series. Computer \& Geosciences, 28 (3), 421-426, doi: 10.1016/S00983004(01)00044-9.

Schwab, C., Kinkel, H., Weinelt, M. and Repschlaeger, J., 2012. Coccolithophore paleoproductivity and ecology response to deglacial and Holocene changes in the Azores Current System. Paleoceanography 27(3), PA3210, doi: 10.1029/2012pa002281.

Shackleton, N.J., Hall, M.A. and Vincent, E., 2000. Phase relationships between millennialscale events 64,000 - 24,000 years ago, Paleoceanography 15 (6), 565- 569, doi: 10.1029/2000PA000513.

Skinner, L.C., Shackleton, N.J., and Elderfield, H., 2003. Millennial-scale variability of deep-water temperature and $\delta^{18} \mathrm{O}_{\mathrm{dw}}$ indicating deep-water source variations in the Northeast 
879

880

881

882

883

884

885

886

887

888

889

890

891

892

893

894

895

896

897

898

899

900

901

902

903

904

905

906

907

908

909

910

911

Atlantic, 0-34 cal. ka BP. Geochemistry Geophysics Geosystems 4(12), 1098, doi: 10.1029/2003GC000585.

Stepanchuk, V. N., and Moigne, A.-M., 2016. MIS 11-locality of Medzhibozh, Ukraine: Archaeological and paleozoological evidence. Quaternary International, 409 (Part B), 241-254, doi: 10.1016/j.quaint.2015.09.050.

Thomson, D. J., 1990. Time series analysis of Holocene climate data. Philosophical Transactions of the Royal Society of London. Series A 330, 601-616.

Trigo R.M., Pozo-Vazquez D., Osborn T. J., et al. 2004. North Atlantic oscillation influence on precipitation, river flow and water resources in the Iberian Peninsula. International Journal of Climatology 24, 925-944.

Tzedakis P. C., 2010. The MIS 11 - MIS 1 analogy, southern European vegetation, atmospheric methane and the "early anthropogenic hypothesis". Climate of the Past, 6, 131-144, doi: 10.5194/cp-6-131-2010.

Tzedakis P. C., Channell J. E. T., Hodell D. A., Kleiven H. F., and Skinner L. C., 2012. Determining the natural length of the current interglacial. Nature Geoscience, 5(2), 138-141, doi: 10.1038/ngeo1358.

Vázquez Riveiros, N., Waelbroeck, C., Skinner, L., Duplessy, J. C., McManus, J. F., Kandiano, E. S., and Bauch, H. A., 2013. The "MIS 11 paradox" and ocean circulation: Role of millennial scale events. Earth and Planetary Science Letters, 371-372, 258-268, doi: 10.1016/j.eps1.2013.03.036.

Voelker, A. H. L., Rodrigues, T., Billups, K., Oppo, D. W., McManus, J. F., Stein, R., Hefter, J., and Grimalt, J. O., 2010. Variations in mid-latitude North Atlantic surface water properties during the mid-Brunhes (MIS 9-14) and their implications for the thermohaline circulation. Climate of the Past 6, 531-552, doi:10.5194/cp-6-531-2010.

Wanner, H. Beer, J., Bütikofer, J., Crowley, T. J., Cubasch, U., Flückiger, J., Goosse, H., Grosjean, M., Joos, F., Kaplan, J. O., Küttel, M., Müller, S. A., Prentice, I. C., Solomina, O., Stocker, T. F., Tarasov, P., Wagner, M., and Widmann, M., 2008. Mid- to Late Holocene climate change: an overview. Quaternary Science Reviews, 27 (19-20), 1791-1828, doi: 10.1016/j.quascirev.2008.06.013.

Wassenburg, J. A., Dietrich, S., Fietzke, J., Fohlmeister, J., Jochum, K. P., Scholz, D., Richter, D.K., Sabaoui, A., Spötl, C., Lohmann, G., Andreae, M. O., and Immenhauser, A., 2016. Reorganization of the North Atlantic Oscillation during early Holocene deglaciation. Nature Geoscience, 9, 602-, http://dx.doi.org/10.1038/ngeo2767. 
Weirauch, D., Billups, K., and Martin, P., 2008. Evolution of millennial-scale climate variability during the doi:10.1029/2007PA001584.

Winter, A., Jordan, R.W., Roth, P.H., 1994. Biogeography of living Coccolithophores in ocean waters. In: Winter, A., Siesser, W.G. (Eds.), Coccolithophores. Cambridge University Press, Cambridge, pp. 199-218.

Yin Q. Z., and Berger A., 2010. Insolation and $\mathrm{CO}_{2}$ contribution to the interglacial climate before and after the Mid-Brunhes Event. Nature Geoscience, 3(4), 243-246. http://dx.doi.org/10.1038/ngeo771.

Zeeden, C., Hilgen, F., Westerhold, T., Lourens, L., Röhl, U., and Bickert, T., 2016. Revised Miocene splice, astronomical tuning and calcareous plankton biochronology of ODP Site 926 between 5 and 14.4 Ma. Palaeogeography, Palaeoclimatology, Palaeoecology, 369, 430-451, https://doi.org/10.1016/j.palaeo.2012.11.009.

\section{Figure captions}

Figure 1. Core location and modern surface oceanographic and atmospheric setting off western Iberia for Spring-Summer (A) and Autumn-Winter (B) (modified from Palumbo et al., 2013b). IL = Icelandic Low; $\mathrm{AH}=$ Azores High; $\mathrm{NAC}=$ North Atlantic Current; AzC = Azores Current; IPC = Iberian Poleward Current; ENACWst= Eastern North Atlantic Central Waters of subtropical origin; ENACWsp= Eastern North Atlantic Central Waters of subpolar origin.

Figure 2. Deglaciation and precession cycle alignments of the last $24 \mathrm{ka} \mathrm{BP}$ and 445-360 ka intervals. In the top panel, the black line shows the SST $\left({ }^{\circ} \mathrm{C}\right)$ data for 445-360 ka (Rodrigues et al., 2011) and the colored lines the SST record for the last 24 ka BP (Rodrigues et al., 2010) according to the deglaciation (magenta) and precession (red) alignments. Stippled lines in the bottom panel indicate the precession amplitude (Berger and Loutre, 1991) for the interval 445-360 ka (black) and the last $24 \mathrm{ka} \mathrm{BP}$ (red), respectively.

Figure 3. Comparison of coccolithophore assemblage and alkenone data for MIS 1 vs. MIS 11. From bottom to the top in each panel: paleoproductivity proxy (i.e., total nannofossil accumulation rate for MIS 1 and small Gephyrocapsa accumulation rate for MIS 11); subpolar surface waters proxies ( $\%$ C. pelagicus ssp. pelagicus and $\left.\% \mathrm{C}_{37: 4}\right)$. Colored vertical bars represent periods of major specific surface-ocean current persistence: yellow for Portugal Current (PC); cyan for subpolar surface waters (SPWs); green for surface-ocean instability; pink for Iberian Poleward Current (IPC) 
transporting ENACWst. Stratigraphic abbreviations are: Ht 4 for Heinrich-type event 4; T (as in TV, TIa) for Termination; YD for Younger Dryas; B/A for Bølling-Allerød; H1 for Heinrich event 1; LGM for last glacial maximum; GS for Greenland stadial; and GI for Greenland interstadial.

Figure 4. Additional coccolithophore assemblage data for MIS 1 vs. MIS 11. From bottom to the top in each panel: Iberian Poleward Current (IPC) proxy (\% U. sibogae); Azores Current (AzC) proxy (\% C. pelagicus ssp. azorinus); surface water oligotrophy proxy (\% F. profunda). Colored vertical bars and stratigraphic abbreviations are the same as in Figure 3.

Figure 5. PCA performed on 445-360 ka and last $24 \mathrm{ka}$ BP intervals. Upper panel: scatter diagrams for the last $24 \mathrm{ka}$ BP between (A) components 1 and 2 and (B) components 1 and 3. Lower panel: scatter diagrams for 445-360 ka interval between (C) components 2 and 1 and (D) components 3 and 1. Tables on the left side provide specification of components used in the analyses (central panel), eigenvalues and percentages of variance for each component with upper table referring to the last $24 \mathrm{ka} \mathrm{BP}$ and lower table to the 445-360 ka interval.

Figure 6. PCA performed for deglaciation period for MIS 2-MIS 1 (19-13.5 ka BP) and MIS 12 MIS 11 (430-425 ka). (A) scatter diagram between components 2 and 1 for MIS 2-MIS 1 deglaciation; (B) scatter diagram between components 3 and 1 for MIS 12-MIS 11 deglaciation. Tables on the left side as in Figure 5.

Figure 7. PCA performed on early-to-mid Holocene (12-7 ka BP) and MIS11c (409-402 ka). (A) scatter diagram between components 3 and 1 for the early-to-mid Holocene; (B) scatter diagram between components 2 and 1 for MIS11c. Tables on the left side as in Figure 5.

Figure 8. Periodograms of investigated taxa obtained using REDFIT for the last 24 ka BP interval. In the periodograms, dotted red lines indicate red noise (Theor AR(1)), green and yellow dotted lines represent $90 \%$ and $95 \%$ significance levels, respectively. Bottom x-axis refers to frequency scale, top $\mathrm{x}$-axis to periodicity scale. Green vertical bars represent the Bandwidth. Numbers on periodograms indicate precession periodicities.

Figure 9. Periodograms of investigated taxa obtained using REDFIT for the 445-360 ka interval. In the periodograms, dotted red lines indicate red noise (Theor AR(1)), green and yellow dotted lines represent $90 \%$ and $95 \%$ significance levels, respectively. Bottom x-axis refers to frequency scale, 
top $\mathrm{x}$-axis to periodicity scale. Green vertical bars represent the Bandwidth. Numbers on periodograms indicate precession periodicities.

Table 1

\begin{tabular}{|c|c|c|c|}
\hline $\begin{array}{l}\text { Coccolithophore } \\
\text { assemblages }\end{array}$ & $\begin{array}{l}\text { Ecological preferences with } \\
\text { main references }\end{array}$ & Alkenone data & $\begin{array}{l}\text { Surface Ocean } \\
\text { Conditions off } \\
\text { Iberian Margin }\end{array}$ \\
\hline U. sibogae & $\begin{array}{l}\text { warm and oligotrophic surface } \\
\text { waters (McIntyre and Bè, 1967; } \\
\text { Brand, 1994; Roth, 1994; López- } \\
\text { Otálvaro et al., 2009; Amore et al., } \\
\text { 2012; Palumbo et al., 2013a, b) }\end{array}$ & $\begin{array}{l}\text { increased alkenones- } \\
\text { derived SST }\end{array}$ & $\begin{array}{l}\text { Iberian } \\
\text { Poleward } \\
\text { Current }\end{array}$ \\
\hline $\begin{array}{l}\text { C. pelagicus ssp. } \\
\text { pelagicus }\end{array}$ & $\begin{array}{l}\text { cold surface waters related to } \\
\text { subpolar front (Parente et al., 2004) }\end{array}$ & $\begin{array}{l}\text { decreased alkenones- } \\
\text { derived SST }\end{array}$ & $\begin{array}{l}\text { subpolar surface } \\
\text { waters }\end{array}$ \\
\hline $\begin{array}{c}\text { small Gephyrocapsa } \\
\text { accumulation rate } \\
\text { (MIS 11); Total } \\
\text { Nannofossil } \\
\text { Accumulation Rate } \\
\text { (MIS1) }\end{array}$ & $\begin{array}{c}\text { nutrient-rich surface waters } \\
\text { (Baumann et al., 2004; López-Otálvaro } \\
\text { et al., 2009; Saavedra-Pellitero et al., } \\
\text { 2011; Amore et al., 2012; Palumbo et } \\
\text { al., 2013a, b) }\end{array}$ & not-relevant & Portugal Current \\
\hline $\begin{array}{l}\text { C. pelagicus ssp. } \\
\text { azorinus }\end{array}$ & $\begin{array}{c}\text { warm surface waters } \\
\text { transported by Azores Current } \\
\text { (Parente et al., 2004) }\end{array}$ & $\begin{array}{l}\text { increased alkenones- } \\
\text { derived SST }\end{array}$ & Azores Current \\
\hline $\begin{array}{l}\text { Sum of cold species } \\
\text { (C. pelagicus }\end{array}$ & cold and nutrient-poor surface & increased $\mathrm{C}_{37: 4} \%$ & $\begin{array}{l}\text { waters with } \\
\text { melting icebergs }\end{array}$ \\
\hline $\begin{array}{c}\text { pelaglcus; } \\
\text { Gephyrocapsa } \\
\text { muellerae/margereli; } \\
\text { Emiliania } \\
\text { huxleyi }>4 \mu \mathrm{m})\end{array}$ & $\begin{array}{l}\text { waters (McIntyre and Bè, 1967; } \\
\text { Breheret, 1978; Roth, 1994; Flores et } \\
\text { al., 1997; Flores et al., 2010; Amore et } \\
\text { al., 2012; Palumbo et al., 2013a, b) }\end{array}$ & $\begin{array}{l}\text { decreased alkenones- } \\
\text { derived SST }\end{array}$ & $\begin{array}{l}\text { cold surface } \\
\text { waters }\end{array}$ \\
\hline
\end{tabular}



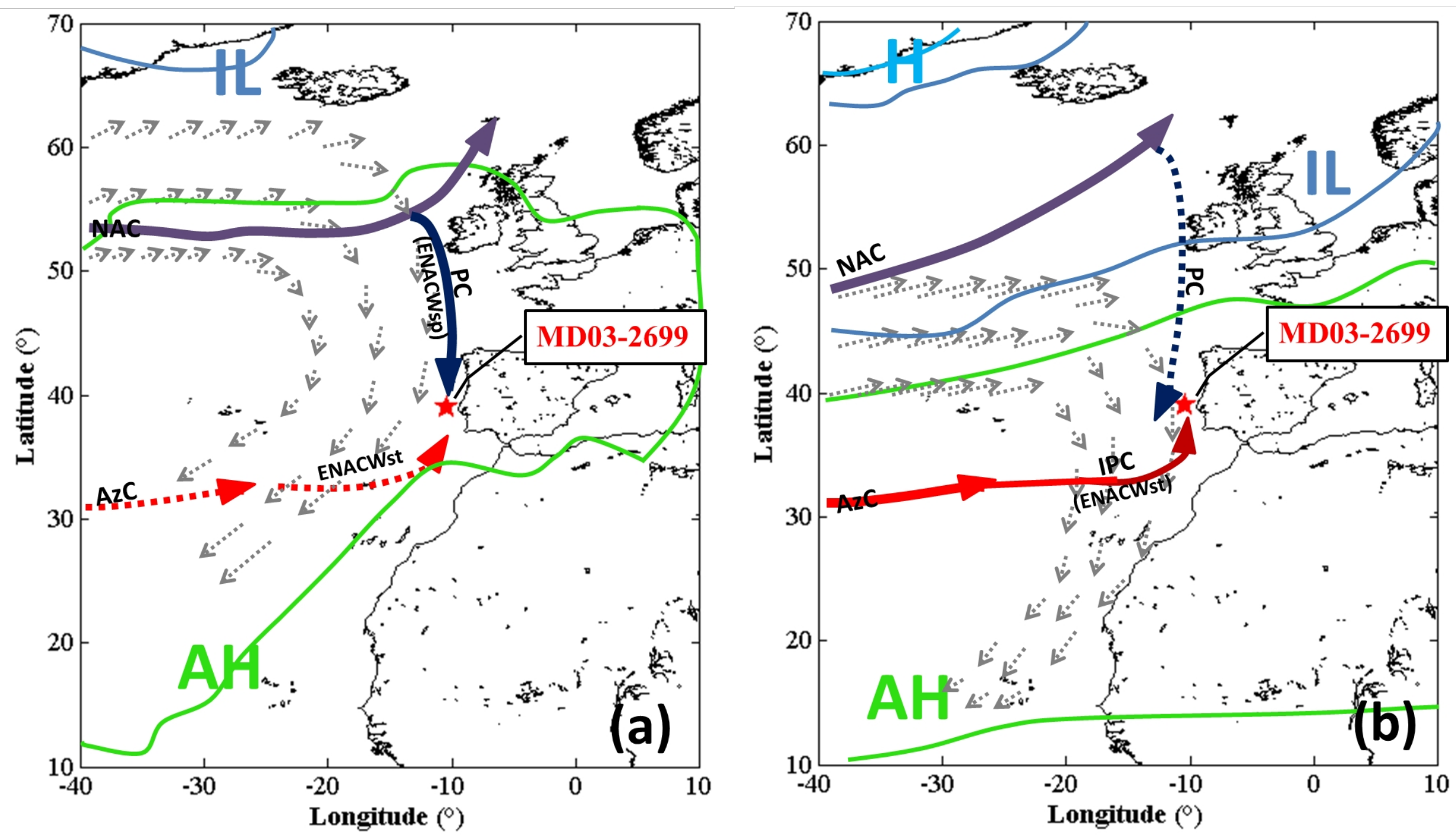
Age (ka BP)
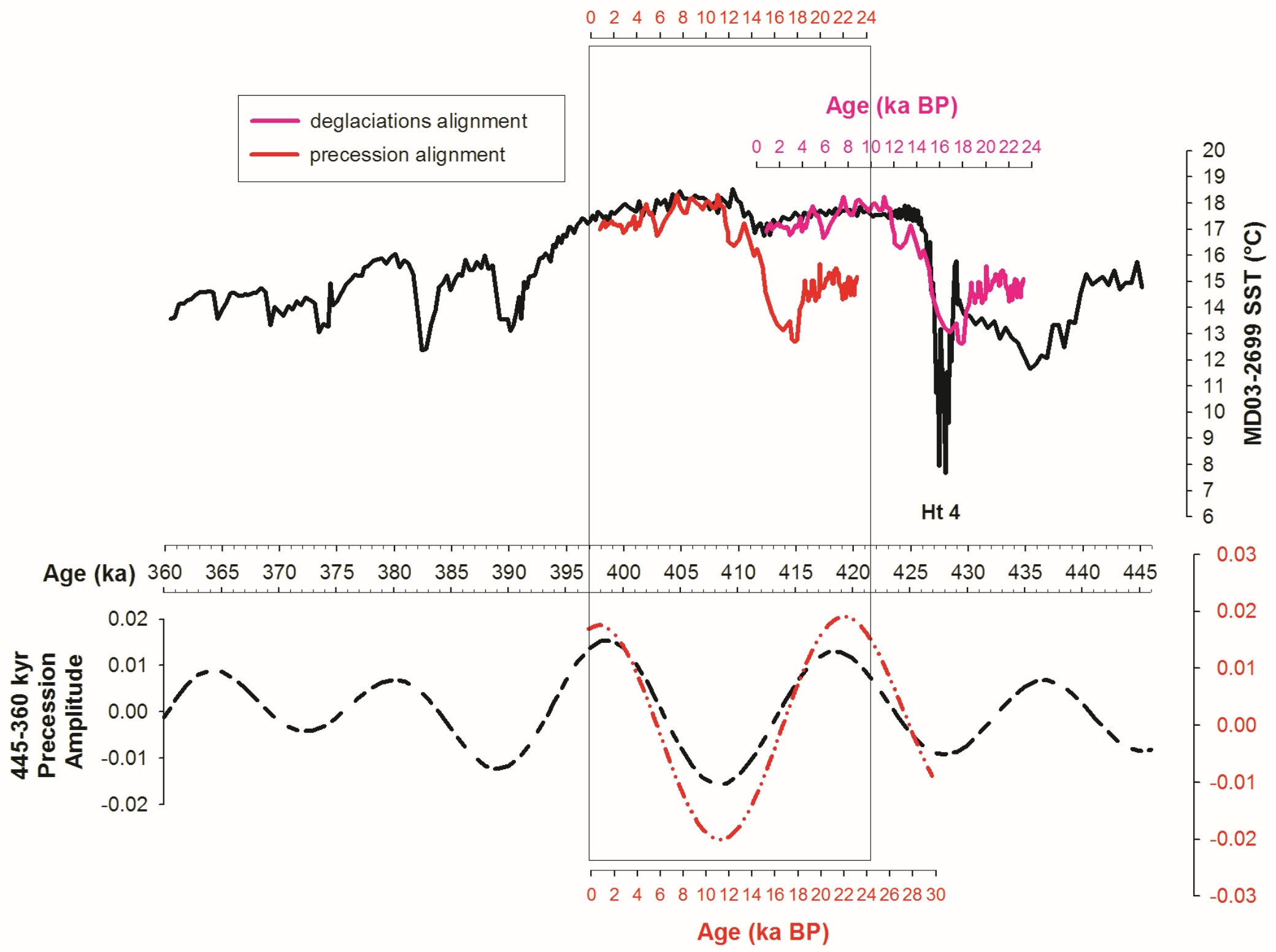

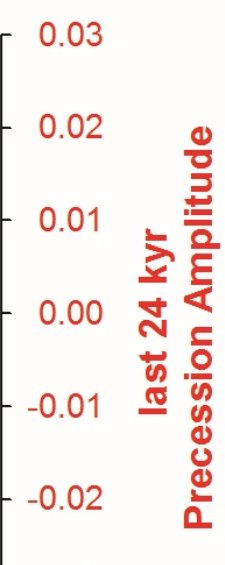




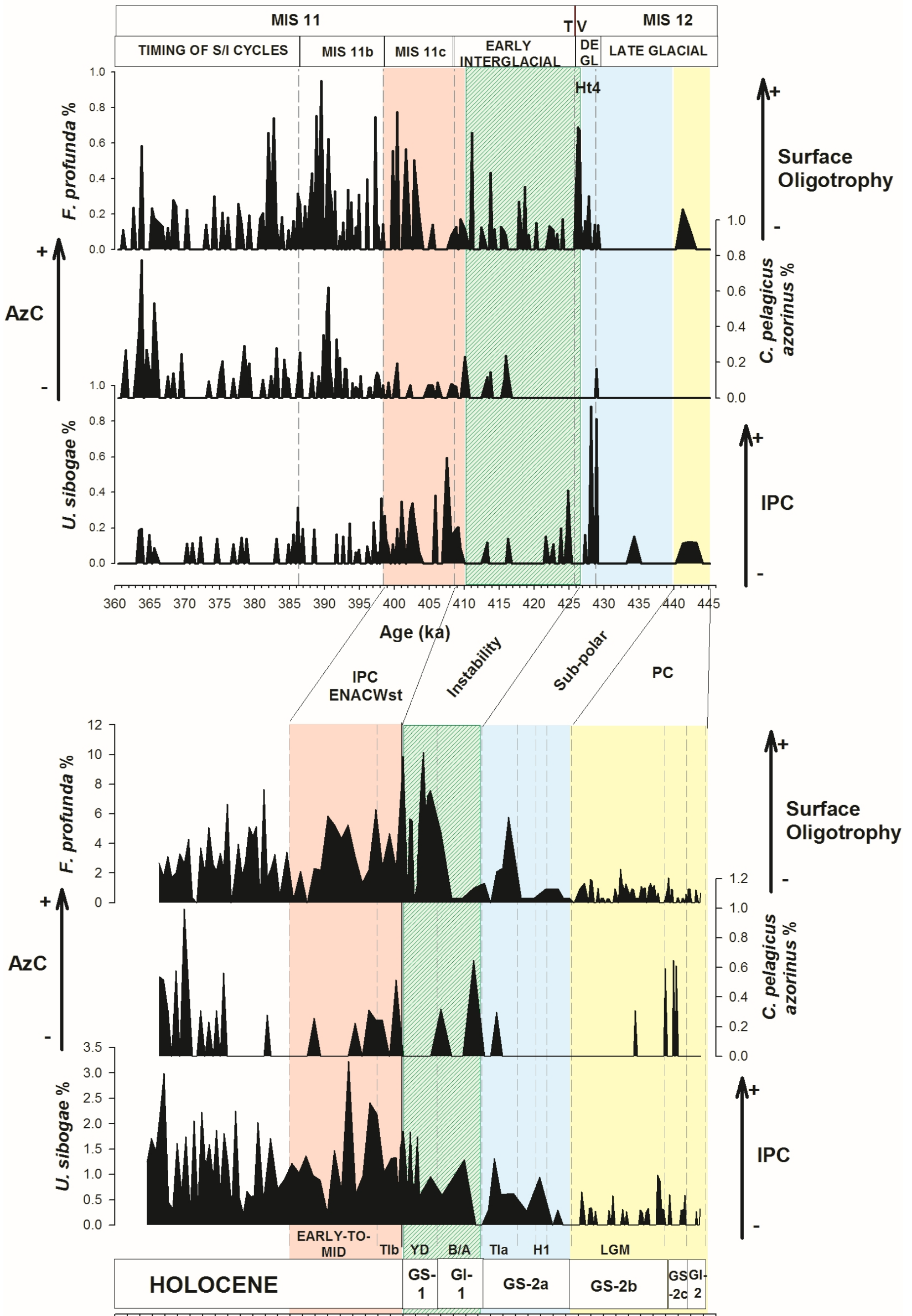

$\begin{array}{lllllllllllllllllllllllll}0 & 1 & 2 & 3 & 4 & 5 & 6 & 7 & 8 & 9 & 10 & 11 & 12 & 13 & 14 & 15 & 16 & 17 & 18 & 19 & 20 & 21 & 22 & 23 & 24\end{array}$

Age (ka BP) 


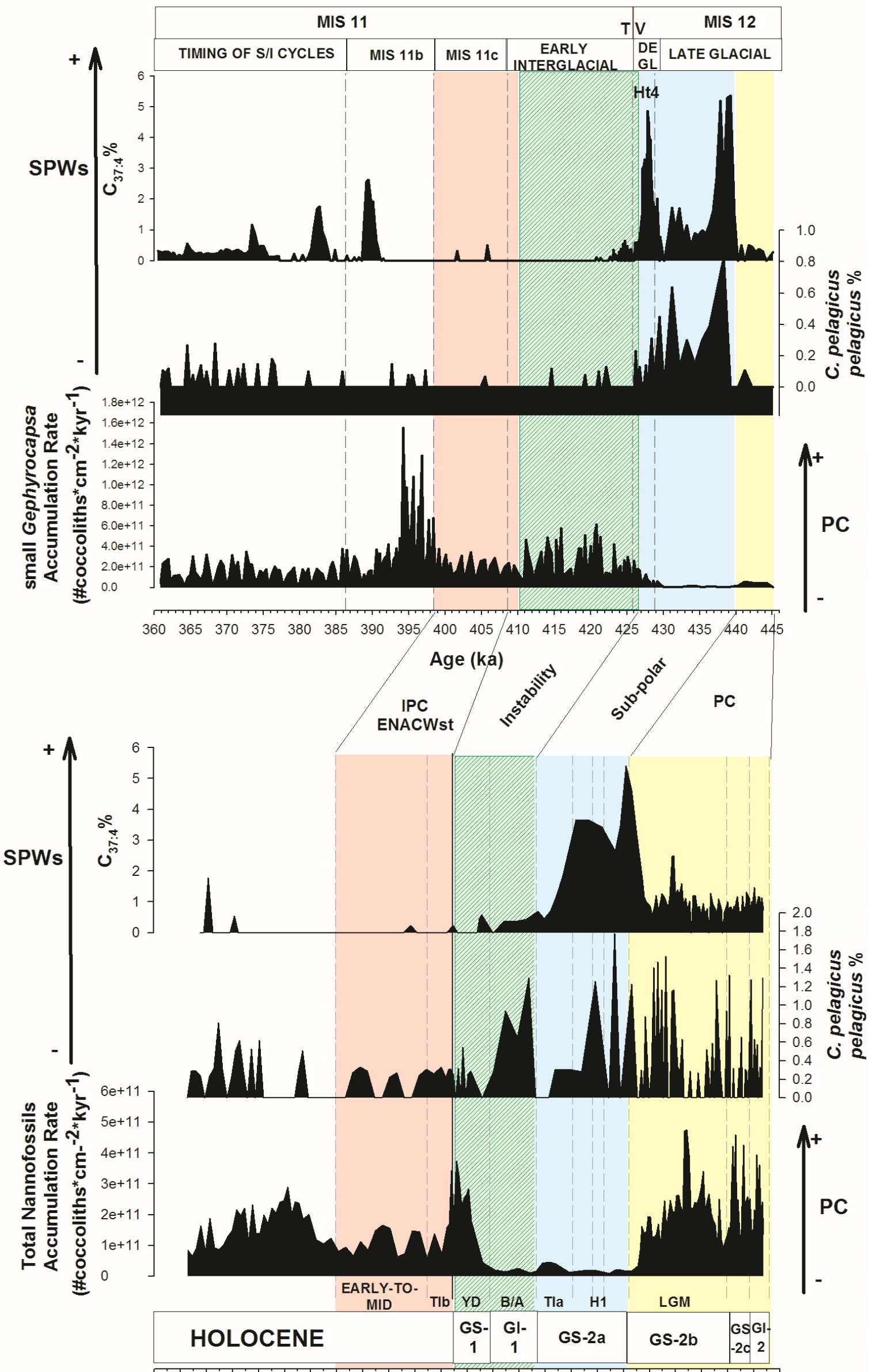

$\begin{array}{lllllllllllllllllllllllll}0 & 1 & 2 & 3 & 4 & 5 & 6 & 7 & 8 & 9 & 10 & 11 & 12 & 13 & 14 & 15 & 16 & 17 & 18 & 19 & 20 & 21 & 22 & 23 & 24\end{array}$

Age (ka BP) 


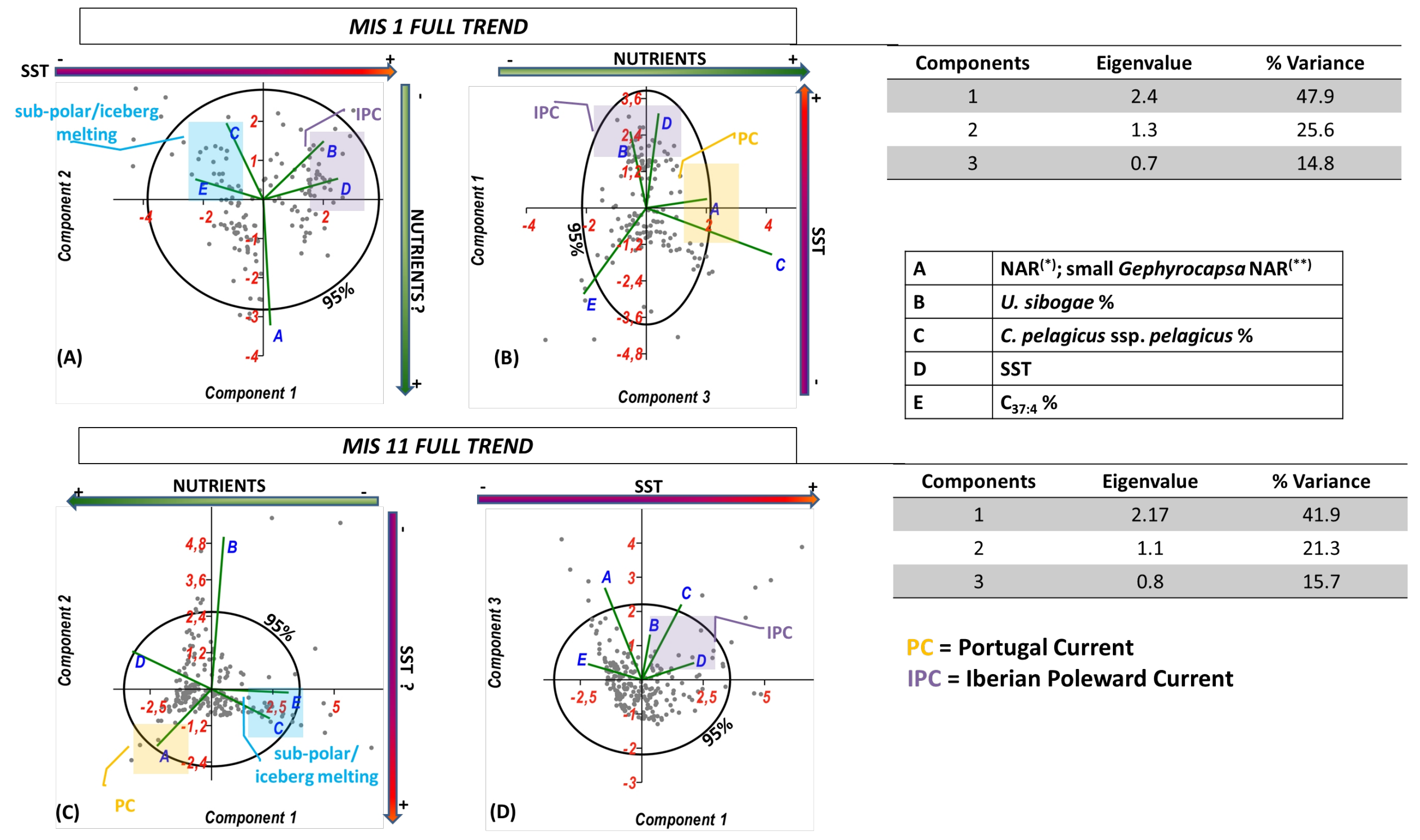




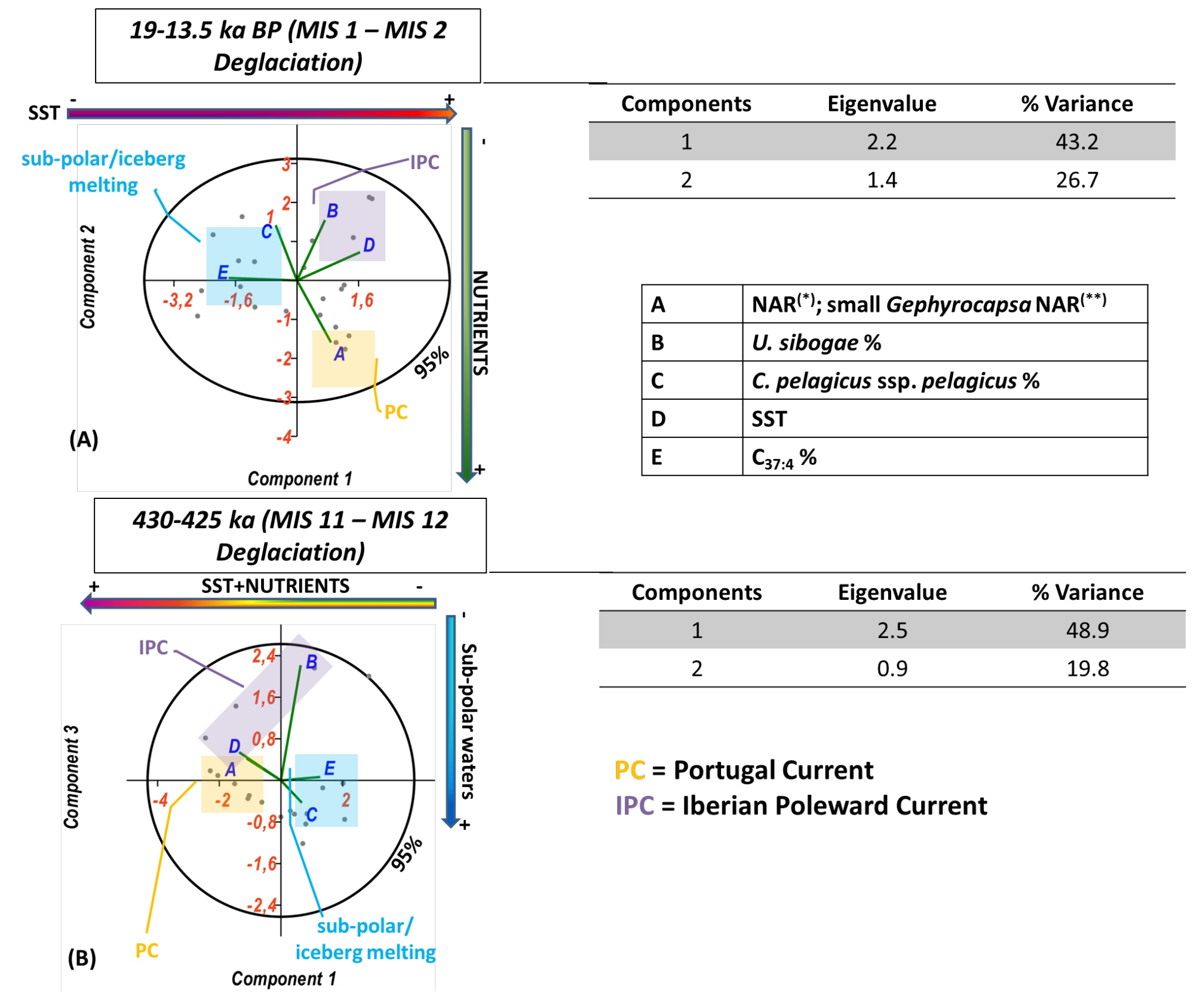




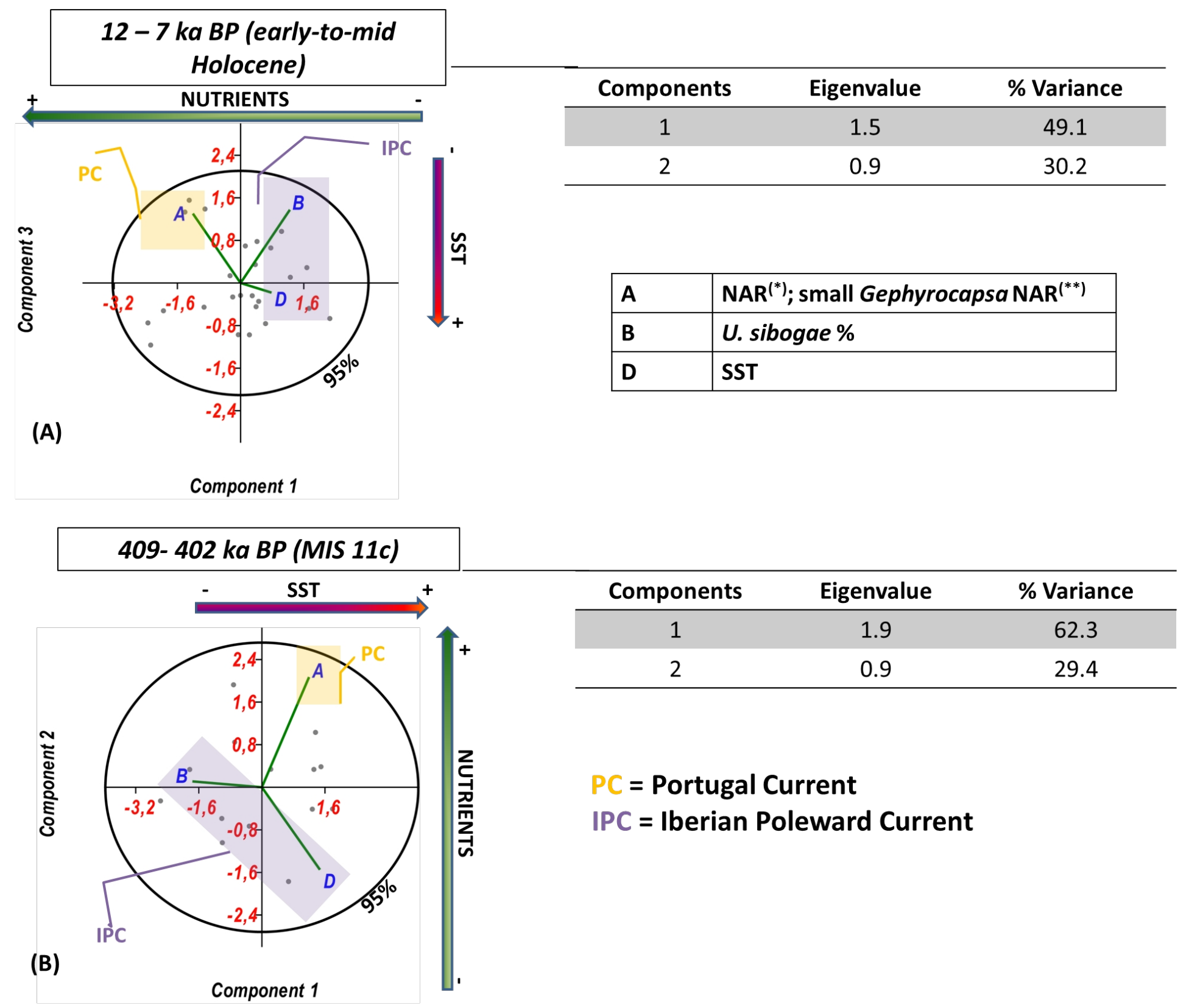


MIS 1 - MIS 2 (0.75-24 ka BP)
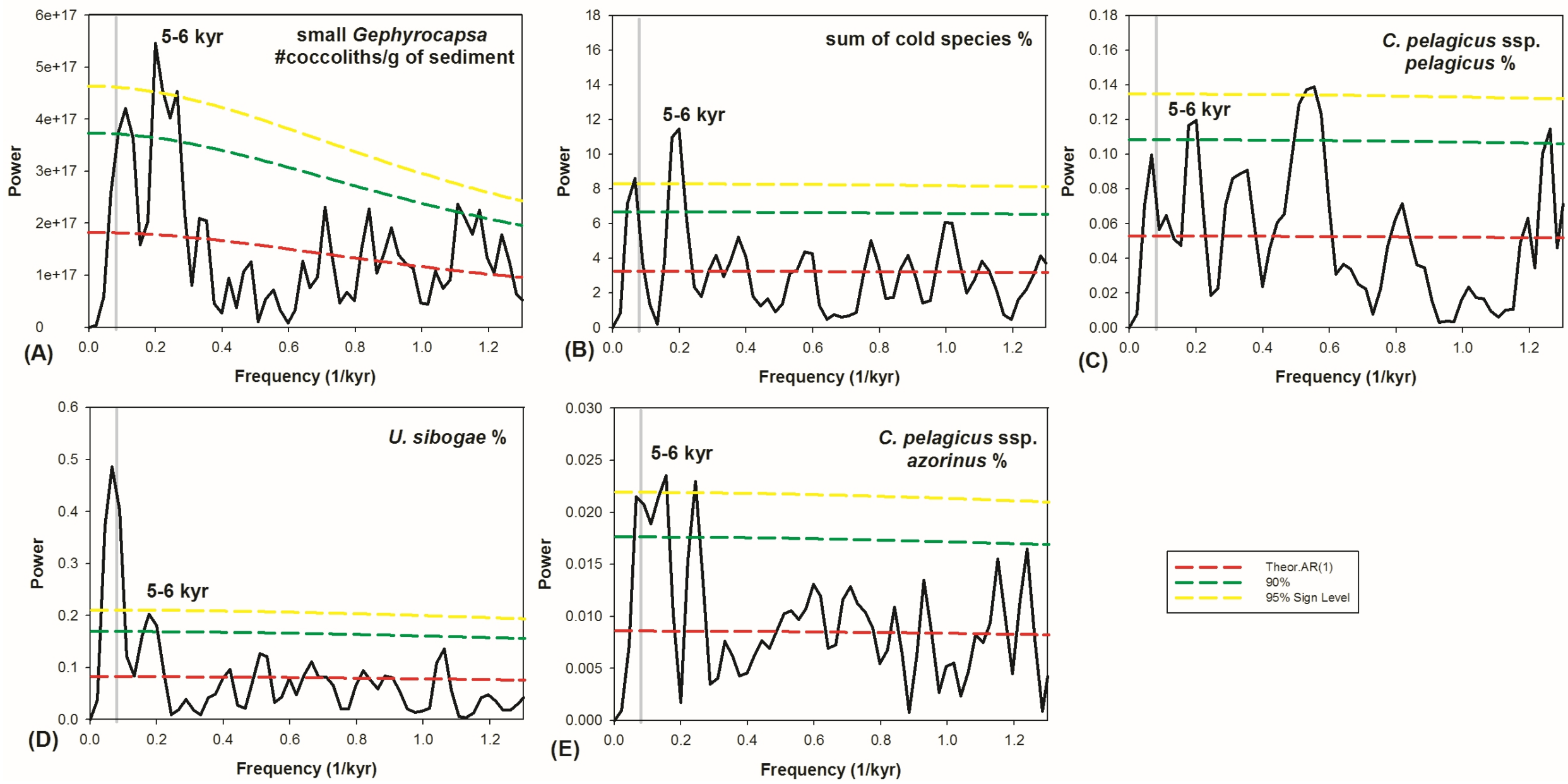

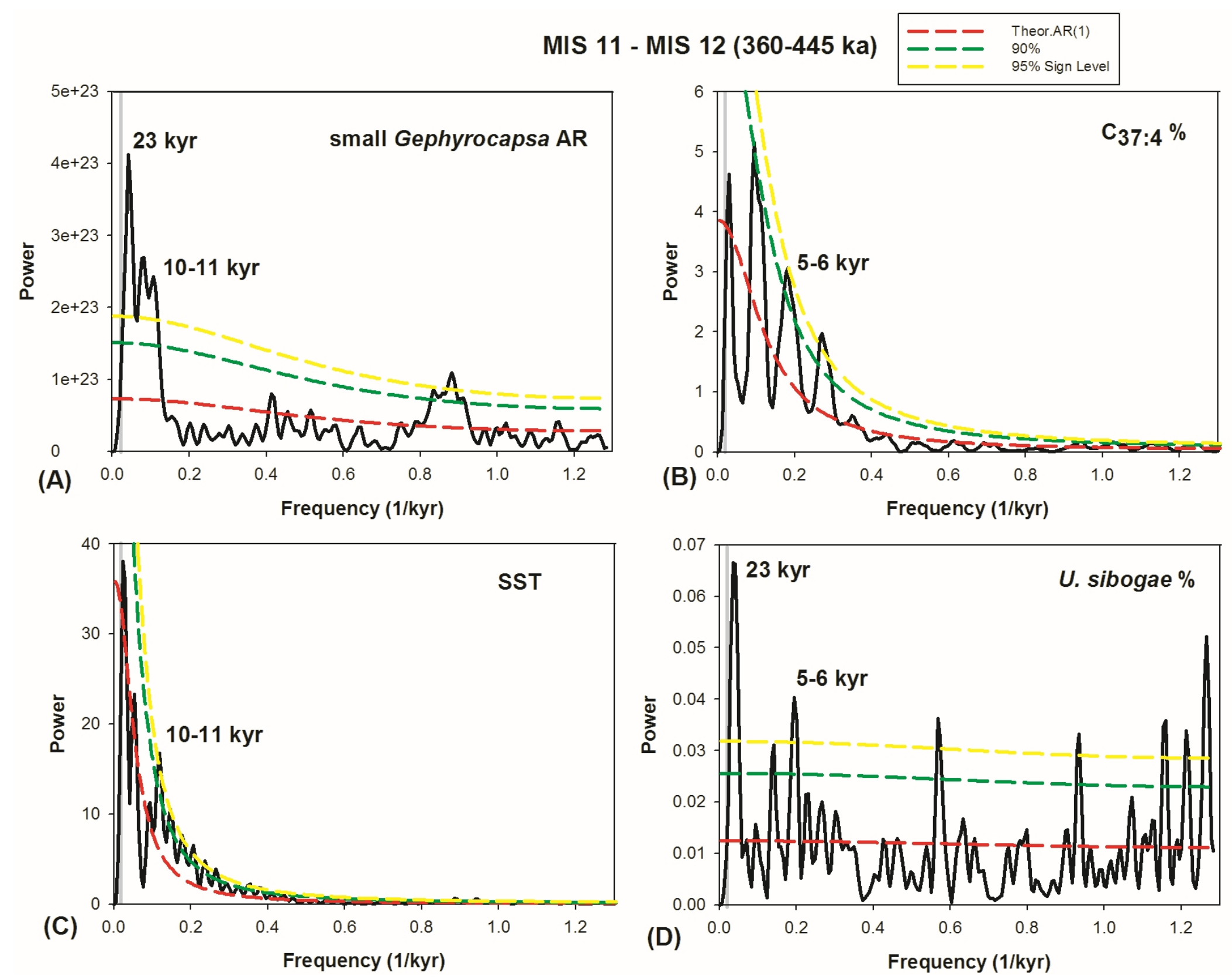